\title{
Aras Valley (northwest Iran): high-resolution stratigraphy of a continuous central Tethyan Permian-Triassic boundary section
}

\author{
Jana Gliwa ${ }^{1}$, Abbas Ghaderi ${ }^{2}$, Lucyna Leda ${ }^{1}$, Martin Schobben ${ }^{3}$, Sara Tomás ${ }^{4}$, William J. Foster ${ }^{1,5}$, \\ Marie-Béatrice Forel $^{6}$, Nahideh Ghanizadeh Tabrizi ${ }^{2}$, Stephen E. Grasby ${ }^{7}$, Ulrich Struck ${ }^{1}$, Ali Reza Ashouri ${ }^{2}$, and \\ Dieter Korn ${ }^{1}$ \\ ${ }^{1}$ Museum für Naturkunde Berlin, Leibniz Institute for Evolution and Biodiversity Science, \\ Invalidenstraße 43, 10115 Berlin, Germany \\ ${ }^{2}$ Department of Geology, Faculty of Science, Ferdowsi University of Mashhad, \\ P.O. Box 9177948974, Mashhad, I. R. Iran \\ ${ }^{3}$ Department of Earth Sciences, Utrecht University, Princetonlaan 8A, Utrecht, the Netherlands \\ ${ }^{4}$ Institute of Earth \& Environmental Sciences, University of Potsdam, \\ Karl-Liebknecht-Straße 24-25, 14476 Potsdam, Germany \\ ${ }^{5}$ School of Earth Sciences, Institute of Geosciences, University College Dublin, Belfield, Dublin 4, Ireland \\ ${ }^{6} \mathrm{CR} 2 \mathrm{P}$, Muséum national d'Histoire naturelle-Sorbonne Université-CNRS, \\ 8 rue Buffon (CP38), 75005, Paris, France \\ ${ }^{7}$ Geological Survey of Canada - Calgary, 3303 33rd St. N.W., Calgary, Alberta, T2L 2A7, Canada
}

Correspondence: Jana Gliwa (jana.gliwa@mfn.berlin)

Received: 21 August 2019 - Revised: 23 December 2019 - Accepted: 17 January 2020 - Published: 21 February 2020

\begin{abstract}
The Permian-Triassic boundary section in the Aras Valley in NW Iran is investigated with respect to carbonate microfacies, biostratigraphy (particularly conodonts, nautiloids, and ammonoids), chemostratigraphy (carbon isotopes), and environmental setting. Correlation of the data allows the establishment of a high-resolution stratigraphy based on conodonts (with four Wuchiapingian, 10 Changhsingian, and three Griesbachian zones), ammonoids (with nine Changhsingian zones), and carbon isotopes; it forms the base for the reconstruction of the environmental changes before and after the end-Permian extinction event at the studied locality. In the Aras Valley section, there is no evidence for the development of anoxic conditions, associated with the end-Permian mass extinction.
\end{abstract}

\section{Introduction}

The end-Permian mass extinction (EPME), which is the most severe biotic crisis of the Phanerozoic (e.g. Erwin 1994, 2002; Benton 2003), has been intensively studied in numerous sections all over the globe. Our knowledge about the co- evolution of life and the planet was affected by this extinction event and the causes of the extinction itself. However, our knowledge derives mainly from sections in only a few regions. High-resolution stratigraphic frameworks have been established in sections of south China, including the Global Boundary Stratotype Section and Point (GSSP) at Meishan, the western USA, and central Europe (e.g. Collinson et al., 1976; Posenato, 2008; Farabegoli and Perri 2012; Yuan et al., 2014; Jattiot et al., 2017). Geochemical proxies for environmental changes (e.g. Horacek et al., 2007a; Marenco et al., 2012; Sun et al., 2012; Yin et al., 2012) and palaeoecological changes have been intensely studied in these regions (e.g. Schubert and Bottjer 1995; Chen et al., 2010; Hofmann et al., 2014, 2015; Foster et al., 2017a, b, 2018). However, to gain insights into global patterns of its manifestation, the EPME has to be studied in detail with a profound stratigraphic framework in numerous regions all over the world.

Permian-Triassic boundary (PTB) sections in northwest Iran and Transcaucasia are well-suited for further detailed investigations concerning the EPME. Unlike many wellstudied sections in south China, the western USA, and central Europe, the Permian-Triassic transition in the Iranian- 
Transcaucasian sections is usually recorded as showing continuous sedimentation. These sections represent a different palaeogeographic region (i.e. the Neotethys Ocean). PTB successions at Iranian and Transcaucasian locations have previously been studied to establish a regional PermianTriassic stratigraphic framework. The sections are known to contain large suites of macrofossils and microfossils, which allow a precise stratigraphic subdivision and correlation with the GSSP section for the Permian-Triassic boundary.

Studies of the Permian-Triassic boundary in the southern Transcaucasus are closely associated with the region west of the two neighbouring towns Dzhulfa (or Culfa; Nakhichevan Province, Azerbaijan) and Julfa (or Jolfa in the literature; East Azerbaijan Province, Iran). Some of the sections, such as Dorasham and the Aras Valley section, are located on the northern and southern banks of the Aras (Araxes) River (Fig. 1a, b). In numerous well-exposed sections, a succession from middle Permian shallow water limestone to late Permian deep shelf sediments and Early Triassic carbonates can be investigated here. Among the many PTB sections in NW Iran and Transcaucasia, the three best-known are

1. Dorasham in Nakhichevan, Azerbaijan (e.g. Arakelyan et al., 1965; Ruzhencev et al., 1965; Rostovtsev and Azaryan, 1973; Kotlyar et al., 1983; Baud et al., 1989; Zakharov, 1992);

2. Kuh-e-Ali Bashi, NW Iran (e.g. Stepanov et al., 1969; Teichert et al., 1973; Richoz, 2006; Richoz et al., 2010; Ghaderi, 2014; Ghaderi et al., 2014b; Leda et al., 2014);

3. Zal, NW Iran (e.g. Korte et al., 2004; Kozur, 2005, 2007b; Richoz et al., 2010; Horacek et al., 2007; Leda et al., 2014; Sedlacek et al., 2014; BadriKolalo et al., 2015; Isaa et al., 2016; Zhang et al., 2018).

During the last decade, efforts to study PTB sections have been intensified in NW Iran, resulting in the investigation of new sections (Ghaderi, 2014; Ghaderi et al., 2014b; Leda et al., 2014). One of these new sections, the Aras Valley section, was discovered in 2011 and is located only a few hundreds of metres along the strike of the west of the Dorasham section.

In the following, we investigate the Aras Valley section (NW Iran) for a comprehensive and detailed bioand chemostratigraphic framework, using conodont and ammonoid zonation as well as carbon isotopes. In comparison to the other NW Iranian-Transcaucasian sections, the Aras Valley section shows some differences, concerning, for instance, the fossil content. There are, for example, extremely abundant ostracod assemblages across the PTB and a high abundance and diversity of cephalopods. Conodont data demonstrate that the section offers a complete succession without stratigraphic gaps. The EPME event can be pinpointed at the millimetre scale and the official, conodontbased Permian-Triassic boundary, with the first appearance of the index species Hindeodus parvus, can be determined.
With this stratigraphic framework, we are able to get a better understanding of the depositional setting and changing environmental conditions that occurred around the time of extinction.

\section{History of research}

Permian-Triassic boundary sections in Transcaucasia (Fig. 1a) have a long research history. Already Abich (1878) described fossils, which he considered to be of Carboniferous age, from the vicinity of the old Armenian village Dorasham in the Aras Gorge west of Dzhulfa (now belonging to the Nakhichevan Province of Azerbaijan). Von Möller (1879) discussed this stratigraphic interpretation and found more similarities to the European Zechstein Formation and, therefore, he reinterpreted the age as Early Permian. Subsequent pioneering studies were carried out by F. Frech (1900) and von Arthaber (1900), who introduced the term "Djulfa-Schichten" for fossiliferous strata with numerous brachiopods and ammonoids of Wuchiapingian age. A readable journey report of this expedition was published by V. Frech (1900), including a very precise description of the adverse field work conditions at that time. Stoyanow (1910) subdivided the lithology of the sections in the Aras Gorge into 15 clearly distinguishable units; he presented the first ammonoid occurrences from the late Changhsingian Paratirolites Limestone, a very characteristic nodular limestone unit of 4 to $5 \mathrm{~m}$ thickness.

The classical section near the Dorasham railway station (Dorasham II, Fig. 1b) at the northern side of the Aras River, about $17 \mathrm{~km}$ WNW of Dzhulfa, was studied in detail by Arakelyan et al. (1965) and Ruzhencev et al. (1965). The articles of the Dorasham sections were released in a comprehensive monograph edited by Ruzhencev and Sarytcheva (1965), who also included extensive descriptions of the fossil content with respect to various groups, such as nautiloids (Shimansky, 1965), ammonoids (Ruzhencev and Shevyrev, 1965; Shevyrev, 1965), brachiopods (e.g. Grunt, 1965; Sarytcheva and Sokolskaja, 1965; Sokolskaja, 1965), and ostracods (Belousova, 1965). Rostovtsev and Azaryan (1973) and Kotlyar et al. (1983), who reinvestigated these PTB successions, introduced the new name Dorashamian for the latest Permian stage, with the Dorasham II section (Fig. 1b) as type locality. The conodont succession of the Dorasham II and Sovetashen (Chanakhchi in literature; Fig. 1a) sections was studied by Kozur et al. $(1978,1980)$ and Kozur in Zakharov et al. (2005); these sections were suggested as stratotypes for the PTB (Kotlyar et al., 1993). The Triassic lithological succession in the Transcaucasian sections was further outlined in great detail by Zakharov (1992). He showed that the late Permian Paratirolites Limestone is overlain by almost $2 \mathrm{~m}$ of the latest Permian argillites with a few marly limestone intercalations. The PTB with the first occurrence of Hindeodus parvus is marked by a first, light-green limestone bed 

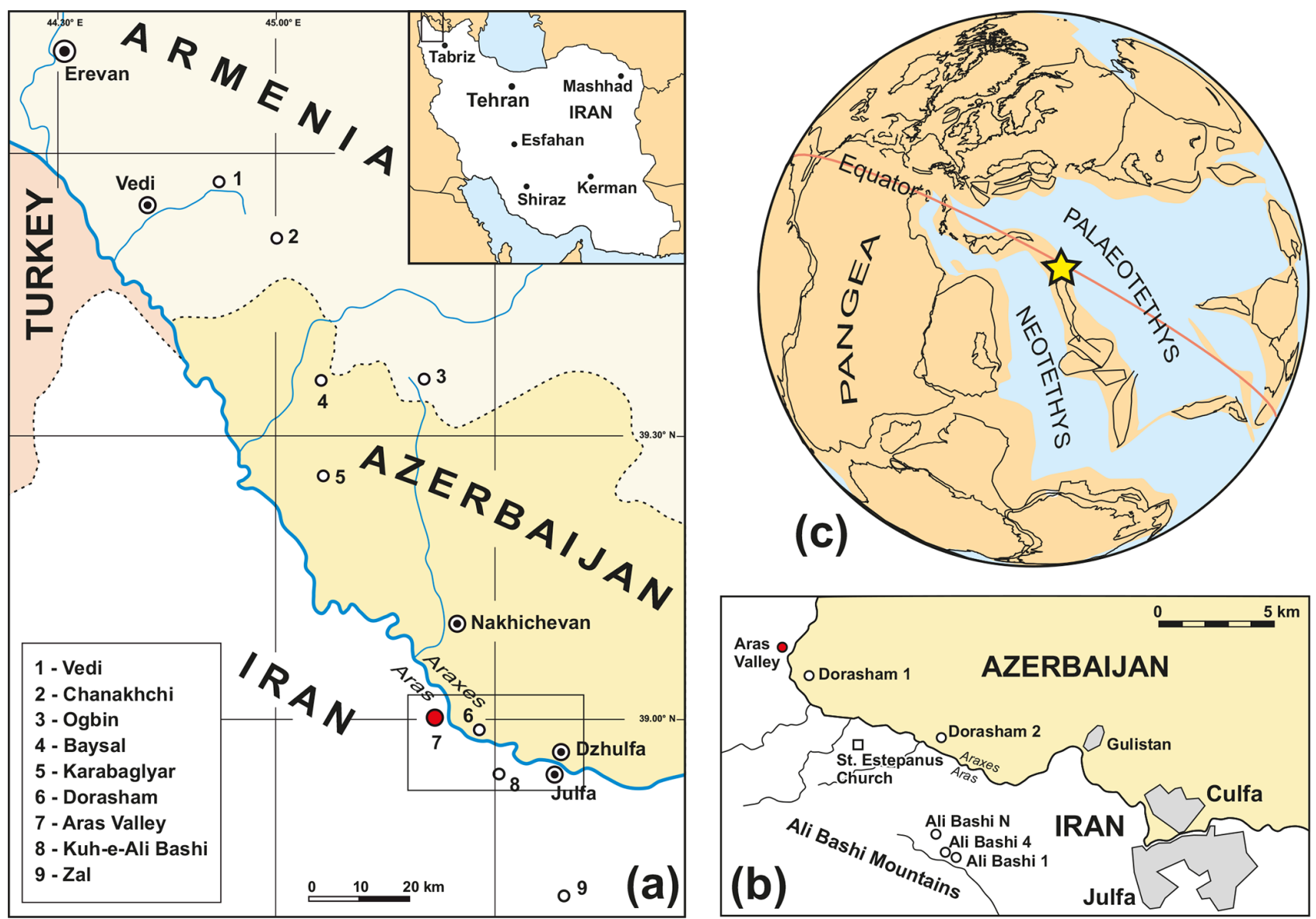

Figure 1. (a) Geographic position of Permian-Triassic boundary sections in the Transcaucasus and in NW Iran (after Arakelyan et al., 1965); important sections are highlighted. (b) Detail map showing the position of the Aras Valley section. (c) Palaeogeographic position of the Julfa area during the PTB time interval (after Stampfli and Borel, 2002).

of $8 \mathrm{~cm}$ thickness, containing bivalves of the genus Claraia. Zakharov's study thus provided one of the most precise determinations of the PTB in the Tethyan realm.

The NW Iranian PTB sections in the Ali Bashi Mountains (Kuh-e-Ali Bashi) west of Julfa were discovered and described by Stepanov et al. (1969) and Teichert et al. (1973). These authors showed striking similarities to the lithological successions of the Dorasham section, which is located approximately $10 \mathrm{~km}$ to the north. In the latter article, Teichert et al. (1973) provided a detailed historical review of the Transcaucasian PTB sections.

In the last 30 years, biostratigraphic (Kozur, 2004a, 2005, 2007b; Mette and Mohtat-Aghai, 2004; Richoz et al., 2010; Shen and Mei, 2010) and chemostratigraphic data (Holser and Magaritz, 1987; Baud et al., 1989; Korte et al., 2004; Korte and Kozur, 2005; Kakuwa and Matsumoto, 2006; Richoz, 2006; Horacek et al., 2007b; Richoz et al., 2010; Sedlacek et al., 2014) for the Ali Bashi and Zal sections were published in a number of articles. A revision of brachiopod, conodont, and ammonoid stratigraphy of the sections near Julfa was done by Ghaderi et al. (2014a, b, 2015), Korn et al. (2016, 2019a), and Korn and Ghaderi (2019). Schobben et al. $(2014,2015,2017)$ presented the stable isotope dynamics with respect to bulk carbonate carbon, bulk carbonate oxygen, carbonate-associated sulfate (CAS), chromiumreducible sulfide (CRS), oxygen isotopes from diagenetically resistant conodont apatite, and oxygen isotopes from low-Mg calcite of well-preserved brachiopods for the Kuhe-Ali Bashi 1 and Zal sections. Sedlacek et al. (2014) studied the strontium isotopes and Zhang et al. (2018) analysed the uranium isotope dynamics in the Zal section. All this led to considerable improvement of the knowledge of geochemical systematics of these sections and, by correlation on a global scale, to a better understanding of the trigger mechanism for the end-Permian mass extinction and its causes.

\section{Geographic and geological setting}

The Aras Valley section (NW Iran; West Azerbaijan Province, $\left.39.0154^{\circ} \mathrm{N}, 45.4345^{\circ} \mathrm{E}\right)$ is situated $19 \mathrm{~km} \mathrm{NW}$ of the towns of Dzhulfa (now Culfa; Azerbaijan) and Julfa 
(or Jolfa; NW Iran) in a dry tributary $200 \mathrm{~m}$ west of the Aras River and $2 \mathrm{~km}$ north-west of the Dorasham I section (Ruzhencev et al., 1965) (Figs. 1, 2). It is located about $11 \mathrm{~km}$ north-west of the Ali Bashi sections, which were already described in detail (Stepanov et al., 1969; Teichert et al., 1973; Ghaderi et al., 2014b; Leda et al., 2014). The Aras Valley section belongs to a north-inclined monocline, which is composed of middle Permian to Triassic sedimentary and volcanic rocks. Half of the Wuchiapingian and a complete Changhsingian succession, as well as the lower part of the Griesbachian sedimentary rocks, are exposed at the Aras Valley section across a lateral extension of $200 \mathrm{~m}$. Particularly the lower, shale-dominated part of the Changhsingian Ali Bashi Formation, the Paratirolites Limestone, and the lower Claraia Beds can be studied in great detail. The Aras Valley section belongs, together with the sections of Dorasham, Ali Bashi, and Zal, to the southernmost PermianTriassic boundary sections of the Transcaucasian-NW Iranian region (Fig. 1). They differ from the northern sections (such as Vedi, Chanakhchi, Ogbin, Karabaglyar, and Baysal) in Armenia and Azerbaijan in the higher shale content of the early Changhsingian strata (Ruzhencev et al., 1965; Rostovtsev and Azaryan, 1973; Kotlyar et al., 1983).

During the late Permian, NW Iran was located at the northern margin of the Sanandaj-Sirjan Terrane as part of the Cimmerian microcontinent (Stampfli and Borel, 2002, 2004). During the Permian, the Cimmerian microcontinent drifted from Gondwana towards the north, paralleled by the opening of the Neotethys; NW Iran was located at a latitudinal position near the Equator between the Neotethys and Palaeotethys (Fig. 1c) (Stampfli and Borel, 2002, 2004; Muttoni et al., 2009a, b). An alternative reconstruction by Ruban et al. $(2007 \mathrm{a}, \mathrm{b})$ suggests that the Sanandaj-Sirjan Terrane and NW Iran were two separated units with NW Iran located east of the Sanandaj-Sirjan Terrane.

During the late Permian to Early Triassic, the SanandajSirjan Terrane was largely covered by a shallow to moderately deep sea; the NW Iranian sections represent mostly open marine deposits (Kozur, 2007b; Leda et al., 2014). The geometry of the NW Iranian carbonate platform has not been studied in detail. Some authors, however, refer to the NW Iranian and Transcaucasian PTB successions as outer-shelf deposits (Kozur, 2007a; Richoz et al., 2010; Ghaderi et al., 2014b; Leda et al., 2014).

\section{Lithostratigraphy}

The Aras Valley section shows a sedimentary succession that is very similar to the neighbouring sections of Dorasham and the Ali Bashi Mountains. It exposes more than $37 \mathrm{~m}$ of sedimentary rock spanning the PTB interval without stratigraphic gaps (Fig. 3). According to the lithostratigraphic scheme developed by Stepanov et al. (1969) and Ghaderi et al. (2014b), the succession of the rock formations is outlined here in as- cending order. For the position of distinct units, beds, and horizons, we use the top of the Paratirolites Limestone as the marker position $(0.00 \mathrm{~m})$.

\subsection{Julfa Formation}

The Permian-Triassic succession in the Aras Valley section begins with the Julfa Formation, of which $15.25 \mathrm{~m}$ (from -29.20 to $-13.95 \mathrm{~m}$ ) was investigated in this study. The Julfa Formation can be subdivided into two members (tentatively named lower and upper Julfa Formation) that differ in rock colour and faunal assemblages (Stepanov et al., 1969).

Lower Julfa Formation. This member was separated into two subunits by Stepanov et al. (1969). The lower unit, which is characterized by abundant occurrences of the large-sized productid brachiopod genus Araxilevis, is poorly exposed in the Aras Valley section and was not investigated in this study. Only the uppermost portion of the member is well-exposed with a thickness of $3.30 \mathrm{~m}$ (from -29.20 to $-25.90 \mathrm{~m}$ ). This part of the lower Julfa Formation is dominantly composed of grey shales with intercalations of grey limestone beds and frequent occurrences of small marly limestone nodules. The limestone intercalations range from single beds $(5$ to $10 \mathrm{~cm})$ to packages of thin-bedded limestones (up to $25 \mathrm{~cm}$ ). Several of the carbonate beds are very fossiliferous and contain benthic (rugose corals, bryozoans, crinoids, ostracods) as well as nektonic (nautiloids, ammonoids, conodonts) fossil organisms. In the upper unit of this member, the brachiopod genera Araxathyris and Permophricodothyris are most common (Ghaderi et al., 2014a). Particularly the cephalopod shells are frequently encrusted by sessile organisms (e.g. tabulate corals, crinoids).

Upper Julfa Formation. The upper member is $12 \mathrm{~m}$ thick (ranging from -25.90 to $-13.95 \mathrm{~m}$ ) and differs from the unit below in the often pinkish to reddish or light-grey shales and limestones. Considering the colour and lithology of the strata, eight subunits, consisting of shale-limestone alternations can be separated, displaying an alteration of reddish and greyish subunits, in ascending order with the thicknesses of $2.75,1.90,1.30,0.70,1.00,0.40,0.70$, and $3.20 \mathrm{~m}$. Specifically, these units are composed of alterations of grey to red shales in packages of 7 to $85 \mathrm{~cm}$ thickness and limestones (often marly). The carbonates are arranged in thin (a few centimetres thick) nodular beds that can form packages up to $1.45 \mathrm{~m}$ in thickness. The carbonate units are often marly and thin-bedded. At the base, the carbonate levels are pink or red and become light grey or beige at the top. The macrofossil content is much lower than in the lower Julfa Formation, recognizable by the much lower occurrences of benthic organisms such as brachiopods and rugose corals. It is noteworthy that fossils of larger nektonic organisms are also rarer; nautiloids and ammonoids have been found only in low numbers. In contrast, ostracods show mass occurrences in some of the higher carbonate beds of the unit. 


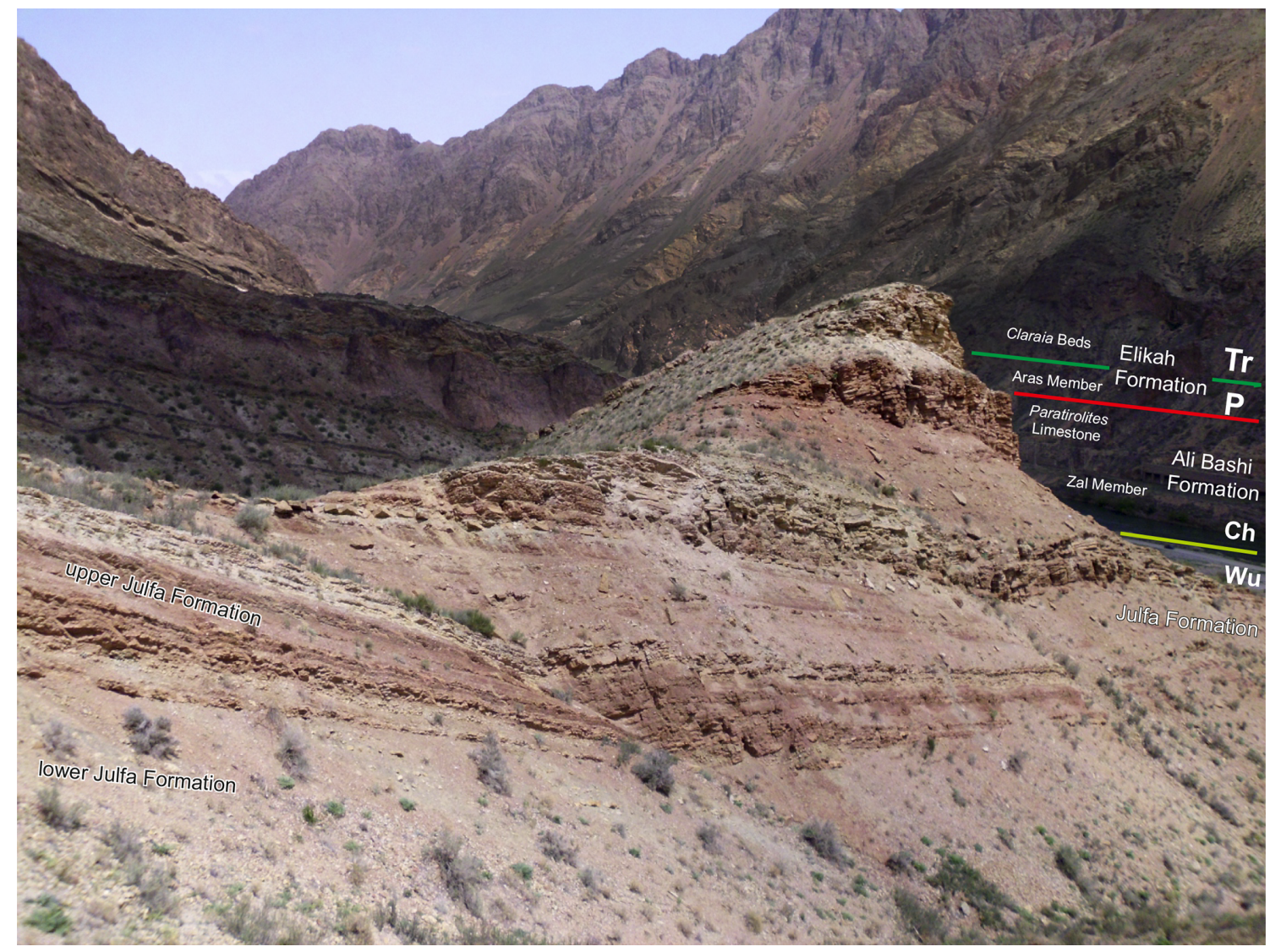

Figure 2. The Permian-Triassic boundary section near the Aras Valley, NW Iran. View towards the north, in the background, beyond the Aras Valley, mountains in Azerbaijan consisting of Triassic rocks.

\subsection{Ali Bashi Formation}

The Ali Bashi Formation is $13.95 \mathrm{~m}$ thick (from -13.95 to $-0.00 \mathrm{~m}$ ) and can be subdivided into two members:

In the Aras Valley section, the Zal Member has a thickness of $9.35 \mathrm{~m}$ (ranging from -13.95 to $-4.60 \mathrm{~m}$ ) and is thinner than in the Ali Bashi 1 section with $12.50 \mathrm{~m}$ (Ghaderi et al., 2014b; Leda et al., 2014). Colour changes of the rocks seen in the underlying upper Julfa Formation continue into the Zal Member, which in turn also shows the alternation of four grey and four red subunits. Shales are the predominant lithology in the Zal member; they range in colour from deep red or purple to greenish or light to dark grey. Some of the shale portions are nearly black when non-weathered. The shales are intercalated with limestones that are usually thin-bedded (up to $5 \mathrm{~cm}$ thick) and marly or, more rarely, silty. Like the shales, their colour is variable and includes reddish, pink, greenish-grey, and grey tones. The upper part of the member shows a decrease in shale content and the limestone beds are amalgamated to form packages up to $55 \mathrm{~cm}$ in thickness. The macrofossil assemblages are dominated by cephalopods, mostly ammonoids (Korn et al., 2019a); some of the beds are very rich in ostracods.
For the Paratirolites Limestone, the member has a thickness of about $4.60 \mathrm{~m}$. The base of the member is not clearly defined; here we consider the base to be marked by a compact limestone bed $(20 \mathrm{~cm}$ thick) that occurs $25 \mathrm{~m}$ above the base of the section (Fig. 3). The unit is mainly composed of thin-bedded (from a few millimetres to $20 \mathrm{~cm}$ in thickness) pink, red, or purple nodular limestones (Ammonitico Rosso facies type). At the base of the member, shaly intercalations of up to $25 \mathrm{~cm}$ in thickness separate the carbonate beds, whereas higher up, the shale horizons become much thinner. Occasionally, the limestone beds are vertically amalgamated, forming packages separated by very thin clay seams. The topmost horizon of the Paratirolites Limestone and its transition to the overlaying Aras Member are marked by a sharp contact. The Paratirolites Limestone yielded a rather high number of ammonoids (Ghaderi et al., 2014b; Korn et al., 2016; Kiessling et al., 2018), while other macrofossils, such as brachiopods and nautiloids, are rare.

Two carbonate horizons deserve particular attention within the Paratirolites Limestone. (1) A $20 \mathrm{~cm}$ thick bed with lightgrey to pink colour (at $-2.20 \mathrm{~m}$ ) serves as a marker horizon in the middle part of the Paratirolites Limestone. It is, in contrast to the other beds, a coarser-grained peloidal- 

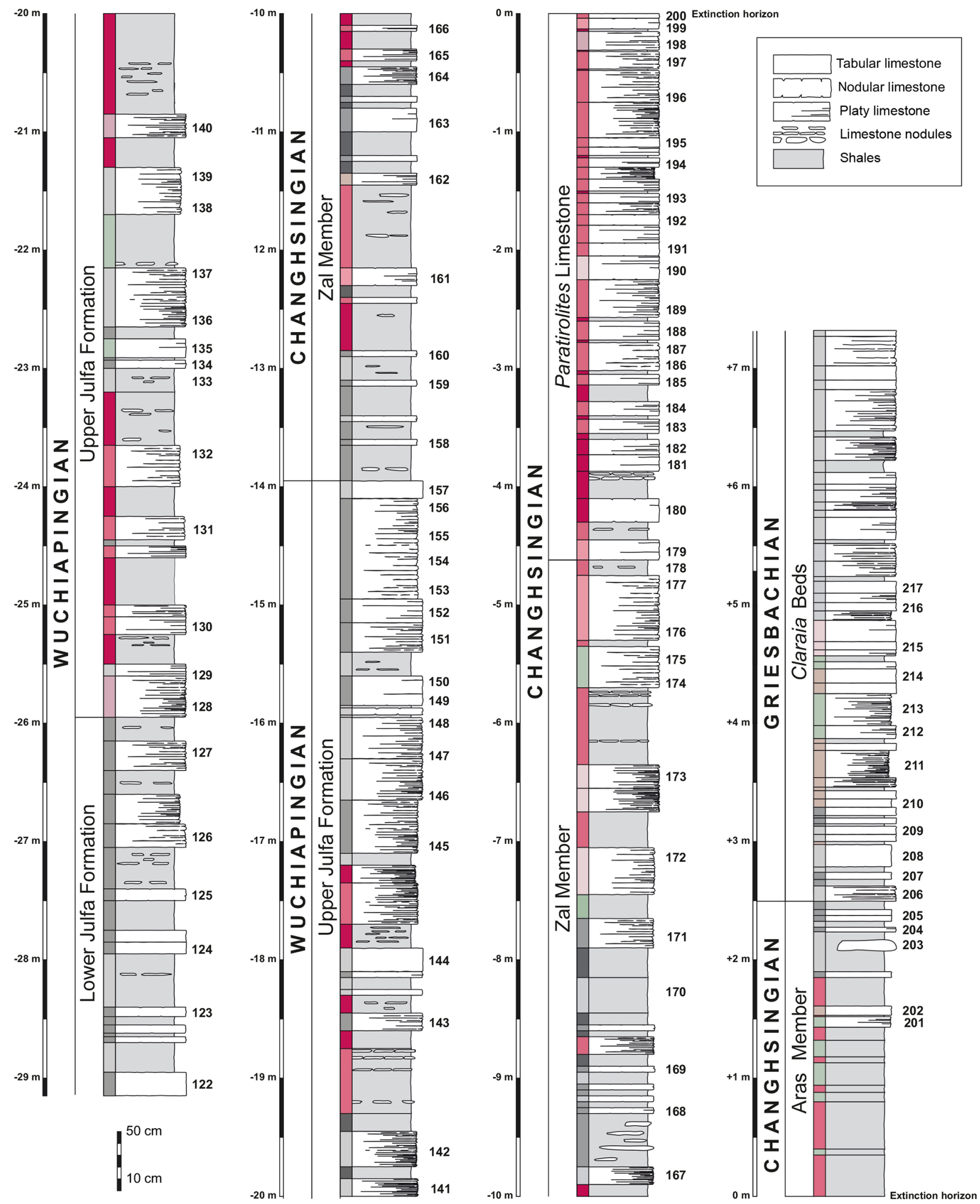

Figure 3. Columnar section of the late Permian to Early Triassic succession in the Aras Valley section with colour indications and numbers of microfacies and conodont samples. 
foraminiferal packstone to grainstone with few calcareous algae fragments (see below). This level can be recognized in similar facies in the neighbouring sections of Ali Bashi (Leda et al., 2014). (2) The top horizon of the Paratirolites Limestone with a $4 \mathrm{~cm}$ thickness displays intensive bioturbation and, in the upper 1.5 to $2 \mathrm{~cm}$, a high accumulation of sponge fibres and other sponge remains.

\subsection{Elikah Formation}

The Elikah Formation reaches a total thickness of around $300 \mathrm{~m}$ in the NW Iranian sections (Stepanov et al., 1969). Only the basal $7.30 \mathrm{~m}$ of the Elikah Formation was analysed and sampled in this study. The Elikah Formation is divided into two members.

The Aras Member ("Boundary Clay") has a thickness of $2.45 \mathrm{~m}$. It consists of purple to pink, greenish-grey, and light to dark grey shales with some marly horizons in the upper part. Some of the horizons show fine laminations caused by ostracod mass occurrences. The top of the unit is placed below the first package of thin-bedded ( $13 \mathrm{~cm}$ thick) light-grey limestone.

Nearly $5 \mathrm{~m}$ of the basal part of the Claraia Beds was logged and sampled $(+2.50$ to $+7.30 \mathrm{~m})$. The total thickness of the complete unit is much greater and contains, like in the Ali Bashi Mountains, thick intervals of subvolcanic sills and volcanic rocks. The basal $0.80 \mathrm{~m}$ of the unit consists of light-grey shales with a few marly limestone interbeds, which are overlain by platy, thin-bedded limestone beds with varying marl content and shaly interbeds. The limestone beds are commonly grouped in packages up to $25 \mathrm{~cm}$ but also occur as individual, single limestone beds of nearly $20 \mathrm{~cm}$ thickness. Their colour is usually grey, but in the lower part also brownish and greenish. The member is very poor in macrofossils; only small specimens of Claraia occur frequently at its base. Ostracods occur frequently in the carbonate beds.

\section{Carbonate microfacies}

The facies distribution of the Aras Valley succession was previously analysed by Leda et al. (2014), who outlined the depositional setting of the sections (Aras Valley, Ali Bashi, Zal) in the Julfa area. In our study, we reinvestigated the Aras Valley section in more detail, as this section differs in some aspects from the sections of Ali Bashi and Zal.

A total of 42 thin sections of limestone beds from -27.90 to +4.95 m (Figs. 4-7) were analysed regarding their textural and compositional characteristics, using transmitted-light and scanning electron microscopy and energy-dispersive Xray spectroscopy (SEM-EDX) spectroscopy. Based on the variations in lithology, texture, and constituents, a total of nine microfacies types have been identified (Fig. 8); a summary of their main characteristics and the measured carbonate content of each sample can be found in Supplement Ta- ble S1. The textural descriptions follow Dunham (1962) and Embry and Klovan (1971) classifications.

\section{Facies 1: crinoidal wackestone}

Facies 1 consists of poorly sorted crinoidal wackestone (locally packstone). The main faunal components are crinoids, brachiopods, gastropods (bellerophontids), and ostracods (disarticulated and articulated carapaces). Ammonoids, undifferentiated shell debris, small foraminifera (mainly lagenids), solitary rugose corals, small fragmented calcareous algae, peloids, and small $(\leq 1 \mathrm{~mm}$ across) rounded to sub-rounded intraclasts with diffused rims are subordinated. The micritic matrix is commonly recrystallized to microspar and/or dolomitized.

\section{Facies 2: peloidal-foraminiferal packstone (with algae)}

The facies consists of a peloidal-foraminiferal packstone (partially grainstone) with diverse small foraminifera (mainly lagenids) (Fig. 6a). The peloids are poorly sorted and occasionally grade into small micritic intraclasts $(\leq 1 \mathrm{~mm}$ across). Ostracods, small fragments of echinoderms, calcispheres, and glauconite grains occur as minor components.

\section{Facies 3: mudstone and wackestone with ostracods}

The facies consists of (commonly bioturbated) mudstone and wackestone (Fig. 4c), in which the predominant biogenic components are ostracods (mostly disarticulated), together with undifferentiated thin shell debris, bivalves, and echinoderm fragments (Fig. 4d). Small foraminifers (mainly lagenids), brachiopods, ammonites, sponge spicules of demosponges, peloids, and poorly sorted rounded to sub-rounded micritic intraclasts (up to $3 \mathrm{~mm}$ ) represent subordinate components. Features of bioturbation and stylolites are common. The matrix is generally recrystallized to microspar and/or dolomitized with occasional occurrences of glauconite grains and glauconitized bioclasts as well as saddle dolomite and manganese dendrites.

\section{Facies 4: burrowed bioclastic mudstone and wackestone}

The facies consists of bioclastic mudstone and wackestone (Figs. 4e, 5a-c). Intense bioturbation is indicated by sub-vertical and horizontal burrows (Fig. 5a, b). Main components are ammonites, fine shell debris (mainly ostracods and thin-shelled bivalves), echinoderm fragments (mainly crinoids), ostracods (articulated and disarticulated), and foraminifera (lagenids). Subordinate components are sponge spicules and other sponge skeletal fragments of demosponges, gastropods, brachiopods, putative radiolarians, intraclasts, and glauconite grains. The intraclasts are micritic and show the same composition as the rock matrix. They are poorly sorted (from less than $1 \mathrm{~mm}$ up to $5 \mathrm{~mm}$ across), rounded to sub-rounded, and occasionally show features of 

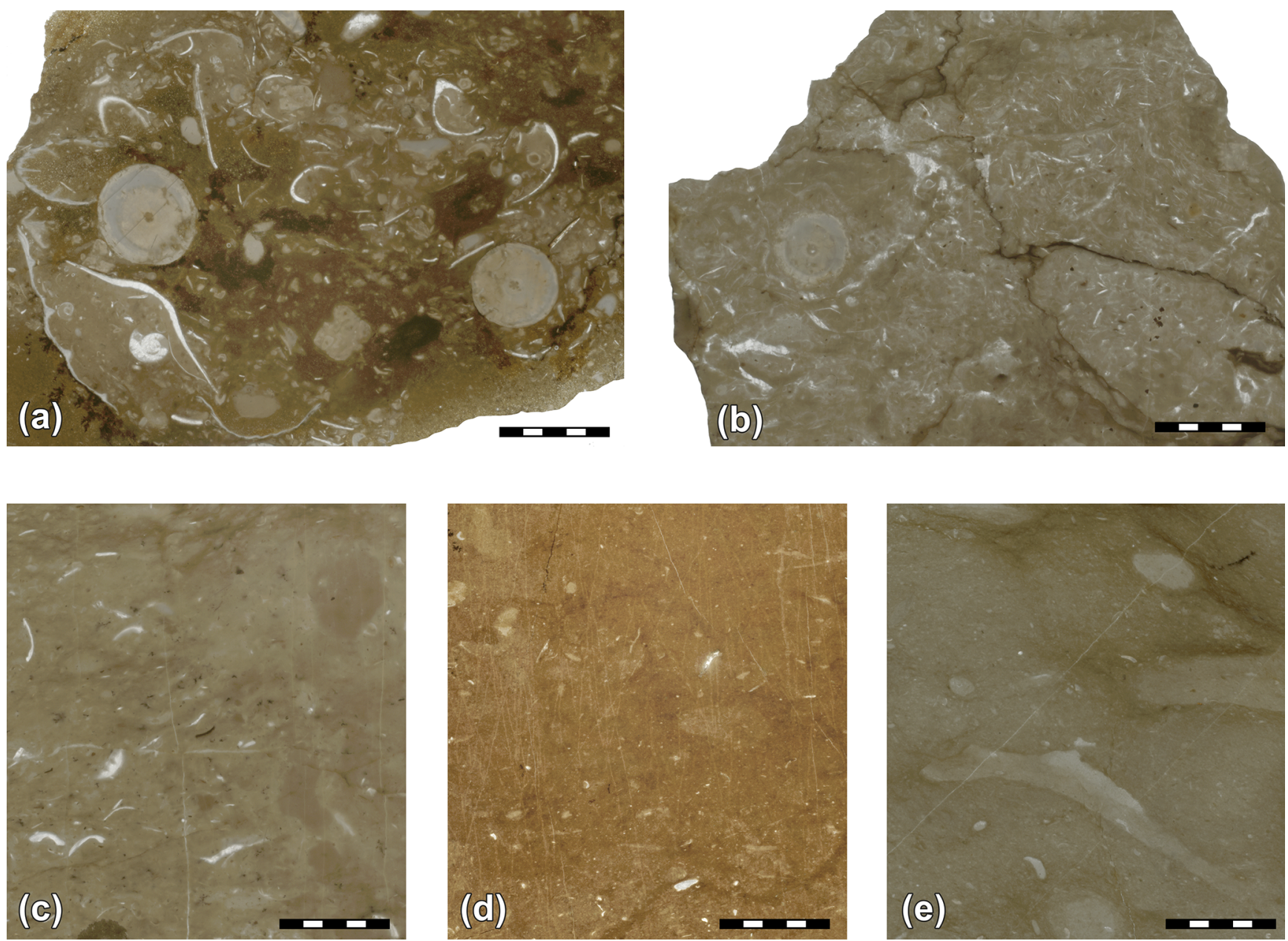

Figure 4. Carbonate microfacies of samples from the lower Julfa Formation (a), upper Julfa Formation (b, c), and Zal Member (d, e) of the Aras Valley section. (a) Crinoidal wacke- to packstone with crinoids, brachiopods, rugose coral, and gastropods as well as peloids in a microspar matrix; sample AJ124 (-27.90 m). (b) Crinoidal wackestone with shell debris and crinoids; sample AJ139 (-21.30 m). (c) Wackestone with disarticulated ostracods, brachiopods, and sub-rounded micritic intraclasts; sample AJ157 ( $-14.00 \mathrm{~m})$. d) Mudstone with ostracod and echinoderm fragments; sample AJ165 (-10.35 m). (e) Burrowed mudstone; sample AJ174 ( -5.65 m). Scale bar units = 1 mm.

ferruginization. The matrix shows small, irregular cavities filled with calcite cements; the matrix is often patchily recrystallized and/or dolomitized. Fractures, manganese dendrites, stylolites, and seams are abundant and give the rock a breccia-like appearance.

\section{Facies 5: burrowed bioclastic-intraclastic wackestone}

Facies 5 has a breccia-like appearance and is compositionally similar to the preceding bioclastic mudstone and wackestone beds of facies 4 . The most significant differences are the higher number of sponge fibres of possible keratose sponges and the higher concentration of intraclasts in the upper half of the unit. The number of intraclasts increases towards the topmost part of the interval; the clasts show the same composition as the rock matrix (bioclastic and spicule-rich wackestone). They are poorly sorted (from less than 1 to $5 \mathrm{~mm}$ across) and are sub-rounded to subangular. Some of the clasts are coated with dark ferruginous crusts and/or encrusted by foraminifera. The matrix shows small, irregular cavities filled with calcite cements. Most common biogens are ostracods, ammonoids, bivalves, sponge spicules and echinoderms, but also foraminifera, and putative radiolarians (Fig. 5d).

\section{Facies 6: sponge packstone}

Facies 6 corresponds to the upper $2 \mathrm{~cm}$ of the topmost $5 \mathrm{~cm}$ thick limestone bed of the Paratirolites Limestone. It consists of coarse-grained packstone with a micritic (occasionally clotted) matrix and conspicuous accumulations of sponge fibres ("sponge spike" following Leda et al., 2014). The sponges are possibly keratose sponges (sensu Luo and Reitner, 2014), which are characterized by a fibre network and lack of spicules; the skeletal parts of the sponges are replaced 

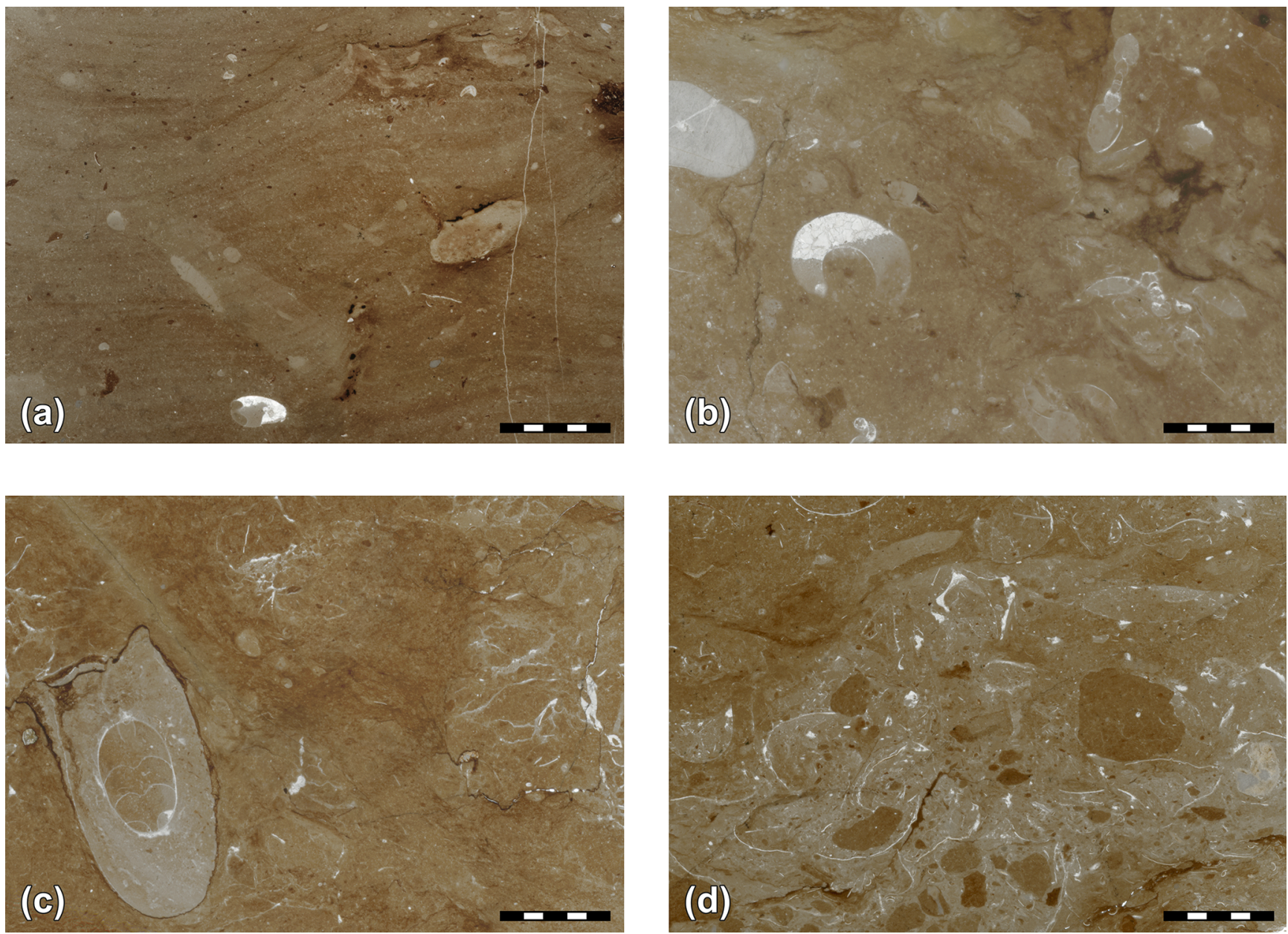

Figure 5. Carbonate microfacies of samples from the Paratirolites Limestone of the Aras Valley section. (a) Burrowed bioclastic mudstone with ammonoids and micritic intraclasts; sample AJ182 (-3.65 m). (b) Burrowed bioclastic wackestone with ammonoids and echinoderms (E); sample AJ186 (-2.95 m). (c) Burrowed bioclastic-intraclastic mudstone with Fe-encrusted ammonoid; sample AJ188 (-2.70 m). (d) Burrowed bioclastic-intraclastic wackestone with shell debris and echinoderms, micrite clasts, and intense brecciation; sample AJ197 $(-0.45 \mathrm{~m})$. Scale bar units $=1 \mathrm{~mm}$.

by calcite. This sponge packstone overlies the preceding facies with a sharp and irregular contact, recognizable in thin sections (Fig. 6c). The matrix is micritic and occasionally clotted. Articulated skeletons and fibres of sponges are the most common bioclasts in this facies, whereas ammonites, gastropods, ostracods, shell fragments, echinoderms, and glauconite are subordinate. The sponge packstone is burrowed and shows internal clotted peloidal structure and small irregular cavities with geopetal infill within the sponge remains. This characteristic sponge packstone facies marks the extinction horizon in all sections between the Aras Valley and the Ali Bashi Mountains (Leda et al., 2014) (Fig. 6c).

\section{Facies 7: burrowed mudstones with sponge remains and calcite crystal fans}

The calcareous intercalations $(+1.70$ to $+2.00 \mathrm{~m})$ of the Aras Member consist of burrowed limestones with sponge remains (fibres) and calcite fan cements. The microfacies consists of mudstone with fragmented sponge networks and fibres (possibly of the keratose sponges). The cements consist of millimetre-scale fans (occasionally crusts) formed by large calcite crystals and small cavities filled with calcite cements. Other minor components are disarticulated and complete ostracods and muddy intraclasts. The matrix is often recrystallized to microspar. In comparison to the Baghuk Mountain section (Leda et al., 2014), the "calcitic fans" of the Aras Valley section do not appear as branching digitate structures. Often, the fans appear to be slumped and/ or reworked, often with characteristic flat and square terminations, radiat- 
ing crystal fibres, spherulites, and mineral splays suggesting that they possibly correspond to aragonite pseudomorphs (Fig. 7a, b). Several types of cement are recognized: (1) microcrystalline with rhombic crystals, (2) bladed crystals with broad, flattened terminations, and (3) heterogranular blocky calcite, characterized by inequigranular, xenotopic, and hypidiotopic fabrics (Leda et al., 2014).

\section{Facies 8: bioclastic (gastropod) mudstone and wackestone}

Facies 8 consists of mudstones and wackestones with diverse bioclasts. The matrix and grains are often recrystallized and/or dolomitized, often hindering the identification of the components. The most abundant components are small gastropods, sponge fibres and other sponge fragments (possibly of keratose sponges) and ostracods. The sponges show internal clotted fabrics and are often burrowed. Small $(\leq 1 \mathrm{~mm}$ across) and rounded micritic intraclasts and occasionally millimetre-scale levels with packstone texture formed by a densely packed concentration of small gastropods and ostracods also occur (Fig. 7c). Coarse-grained calcite spar cements filling large (few centimetres) cavities are visible in the thin section. Bioturbation, pressure-solution seams, and manganese dendrites are also common.

\section{Facies 9: laminated? mudstone with sparry calcite crystals}

The facies consists of fine-grained and crudely laminated mudstone and bindstone (Fig. 7d, e), partially recrystallized, with a few microfossils (ostracods and crinoids). The bindstone is composed of very thin, planar to wavy discontinuous layers of dense or clotted micritic layers, alternated with sparitic layers. Closely spaced equant sparry calcite (occasionally celestine) crystals are incorporated within the laminae. Most of the crystals are concentrated in millimetre-scale layers that are occasionally inversely graded (Fig. 7e). The sparry crystals are $0.5-2 \mathrm{~mm}$ across and show diverse morphologies varying from more or less geometrical to irregular to spherical. Some of the crystals show uniform extinction or contain small euhedral dolomite rhombi. The matrix surrounding the crystals is often recrystallized and indicates clotted micritic fabrics resembling automicrite. The identification of laminae is not straightforward and is often hindered by the pseudo-laminae created by abundant horizontal pressure-solution seams and stylolites.

\section{Depositional environments}

The carbonate litho- and microfacies data (lithology, sedimentary structures, texture, and skeletal and non-skeletal components) collected in the Aras Valley section indicate deposition in open marine, mostly deep, outer-shelf environments dominated by quiet waters.
The upper Julfa Formation and the lower part of the Ali Bashi Formation (facies 1,3) are composed of shales with numerous carbonate beds, which contain fossils of marine organisms (ammonoids, nautiloids, conodonts, putative radiolarians, echinoderms, brachiopods, thin-shelled bivalves, lagenid foraminifera). These indicate a deposition in distal, relatively deep (below storm wave base) and open marine settings. Moreover, the occurrence of a mud-dominated carbonate facies (mudstone and wackestone) and glauconite, as well as the common to intense bioturbation, suggests deposition under low-energy and normal oxic conditions with low sedimentation rates. The occurrence of coarser grainy facies (peloidal-foraminiferal packstone) in the middle part of the upper Julfa Formation may indicate episodic conditions of higher water energy, possibly in open marine, middle-shelf settings.

The facies of the Paratirolites Limestone shows a marked change into nodular fabrics (Ammonitico Rosso facies type), a decrease in shale content, and an increase in pelagic fauna (e.g. ammonoids, putative radiolarians) in comparison to the underlying strata. These faunal and depositional changes indicate a successive deepening upward trend from the Julfa Formation to the Paratirolites Limestone. Therefore, the nodular, bioturbated bioclastic and bioclastic-intraclastic muddy facies of the Paratirolites Limestone (facies 4) was deposited in an open marine and deeper (below wave base; dysphotic zone) shelf setting, mainly dominated by low water energy and low terrigenous input. The commonly intense bioturbation and the relatively diversified benthic macrofauna and microfauna (e.g. crinoids, brachiopods, bivalves, gastropods, and sponges) indicate oxic conditions. A similar deepening trend has been suggested by Ghaderi et al. (2014b) based on the decrease in abundance and diversity of brachiopods. Episodically, the deep and quiet water environment may have changed into a shallower environment with higher water energy (middle shelf) as supported by the grainy facies with peloids, diverse foraminifers, and calcareous algae (facies 2), which characterize the deposits of the middle part of the Paratirolites Limestone.

The facies of the topmost part of the Paratirolites Limestone (facies 5) does not show sedimentological or palaeontological evidence for large-scale sea-level changes but indicates marked variations in the rate of sedimentation. In agreement with previous interpretations for other central and northern Iranian successions (Heydari et al., 2003; Richoz et al., 2010; Leda et al., 2014), the topmost part of the Paratirolites Limestone (bioclastic-intraclastic limestone) is interpreted here to be deposited in an outer-shelf setting. The occurrence of omission or condensation surfaces, breccialike appearance, high concentration of intraclasts (sometimes coated with $\mathrm{Fe}$ crusts or bioencrusted), and the cavities filled with cements are not indicative of subaerial exposure but of early lithification and reworking during conditions of very low sedimentation rates and condensation. Similar interpretations, suggesting a continuous sedimentation without sub- 

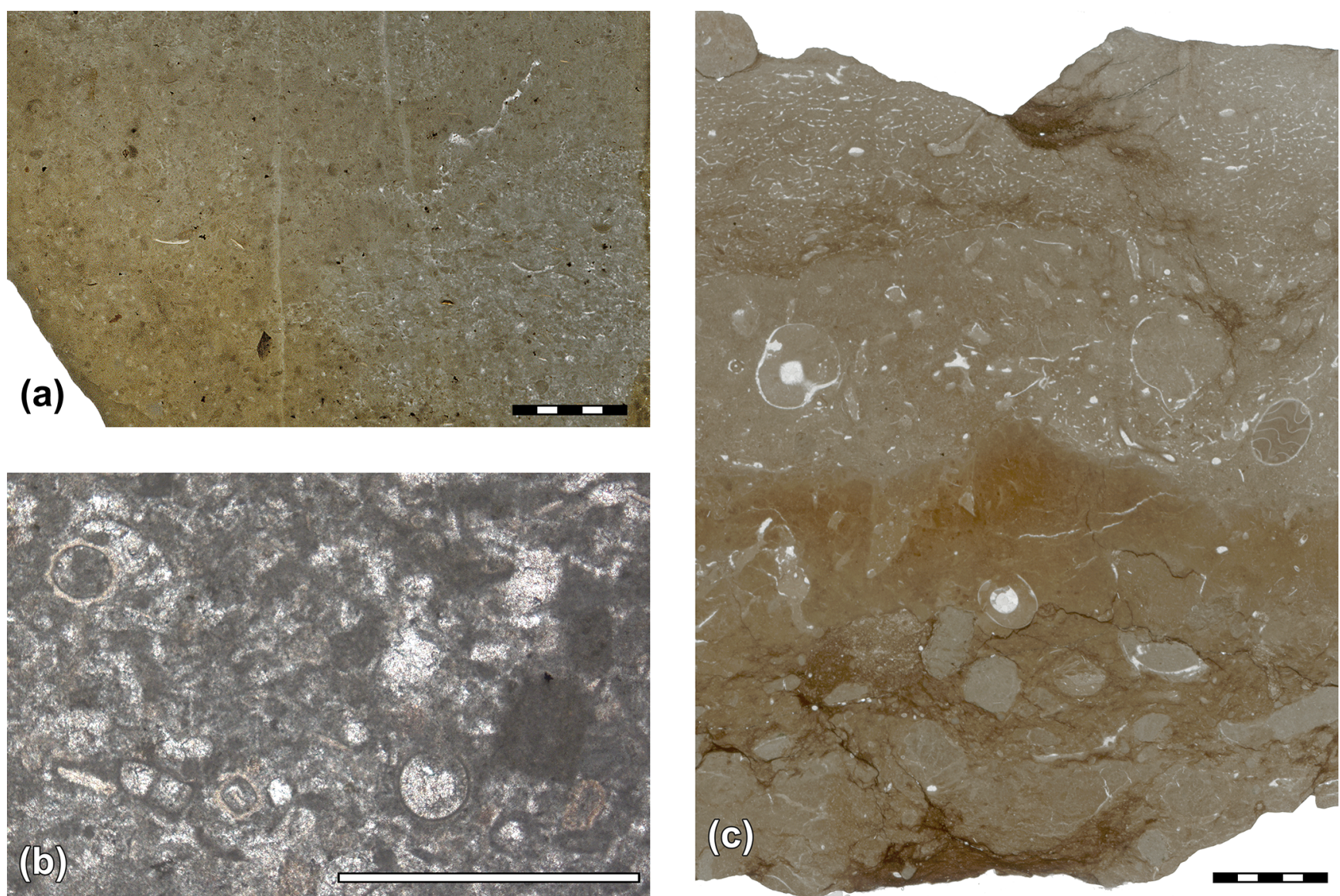

(c)

Figure 6. Carbonate microfacies of samples from the upper Julfa Formation and the Paratirolites Limestone of the Aras Valley section. (a) Peloidal-foraminiferal packstone; sample AJ144 (-18.00 m). (b) Peloidal-foraminiferal packstone with algae; sample AJ190 (-2.20 m). (c) Microfacies sample from the topmost $4 \mathrm{~cm}$ of the Paratirolites Limestone (sample AJ200; $=0.00$ to $-0.04 \mathrm{~m}$ ). Lower part: burrowed bioclastic-intraclastic wackestone with ammonoids, bivalves and ostracods, lithoclasts, and micrite clasts. Upper part: sponge packstone with ammonoids, bellerophontids, and ostracods; uppermost $10 \mathrm{~mm}$ with a densely packed sponge meshwork of possible keratose sponges. Scale bar units $=1 \mathrm{~mm}$.

aerial exposure, have been previously made for the NW Iranian Paratirolites Limestone (Altiner et al., 1980; Richoz et al., 2010; Leda et al., 2014). The conditions of starvation and early lithification of the sea bottom, which are observed for the top Paratirolites Limestone, may have favoured the development and colonization of the substrate by sessile sponges (sponge packstone facies), which characterize the top 1-2 cm of this unit (facies 6). This dense accumulation of keratose sponge remains (sponge spike) may mark the EPME event, as keratose sponges have been previously interpreted as post-extinction facies (Friesenbichler et al., 2018; Heindel et al., 2018; Foster et al., 2020). Similar occurrences, but with a stratigraphically younger position, have been reported from other Tethyan PTB sections in Armenia and central Iran (Richoz et al., 2010; Leda et al., 2014; Friesenbichler et al., 2018; Heindel et al., 2018). In these regions, the sponge network remains are usually associated with microbial, crystal fan-like structures, representing post-extinction spongemicrobial build-ups (Friesenbichler et al., 2018; Heindel et al., 2018; Foster et al., 2020; Martindale et al., 2019), but in this study no clear indication of microbial fabrics is observed.

The facies of the post-extinction Aras Member (Boundary Clay) does not indicate bathymetric or hydrodynamic changes when compared with the Paratirolites Limestone. However, a strong decline and/or cessation of the skeletal carbonate production may have caused the abrupt lithological change from the carbonate-dominated Paratirolites Limestone to the shale-dominated Aras Member. The restart of the carbonate factory in the upper part of the Aras Member is marked by the deposition of burrowed mudstone-wackestone facies with sponges and conspicuous calcite crystal fans and crusts (facies 7). These structures are similar to the calcite crystal fans already known from PTB sections in various regions (Taraz et al., 1981; Baud et al., 1997; Kershaw et al., 1999; Woods et al., 1999; Heydari et al., 2003; Baud et al., 2005a, b; Pruss et al., 2005; Richoz et al., 2010; Friesenbichler et al., 2018). Interpretations of the origin of these structures differ mainly in the hypothesis of whether they were 

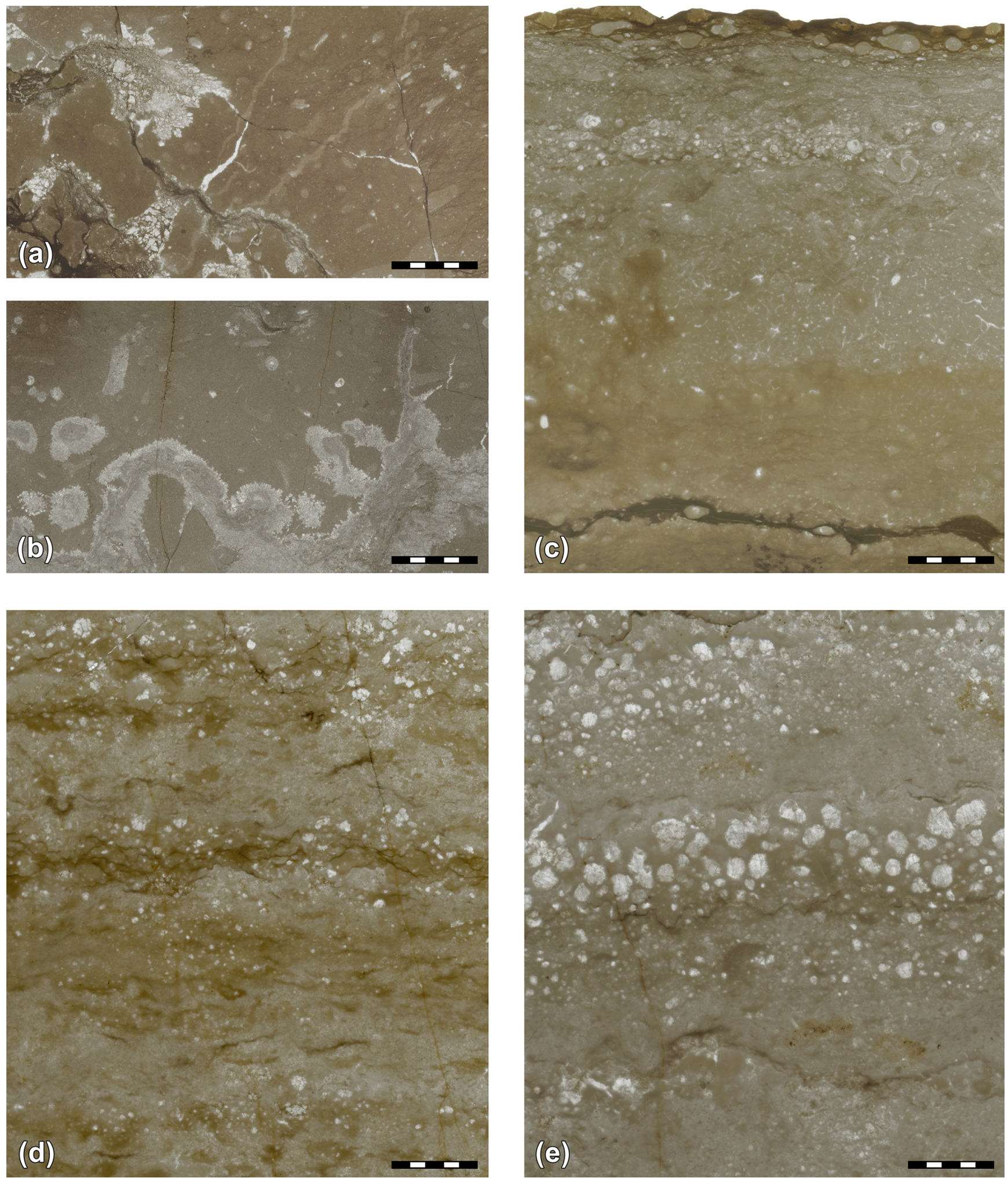

Figure 7. Carbonate microfacies of samples from the Aras Member (a, b) and the Claraia Beds (c-e) of the Aras Valley section. (a) Burrowed mudstone with calcite fan structures; sample AJ202 (+1.65 m). (b) Burrowed mudstone with calcite fans; sample AJ203 (+2.00 m). (c) Gastropod mudstone and wackestone with microgastropods and sponge remains of possible keratose sponges; sample AJ204 (+2.35 m). (d) Laminated mudstone with irregularly shaped sparry calcite crystals; sample AJ210 (+3.80 m). (e) Laminated mudstone with subrounded sparry calcite crystals; sample AJ216 (+4.95 m). Scale bar units $=1 \mathrm{~mm}$. 


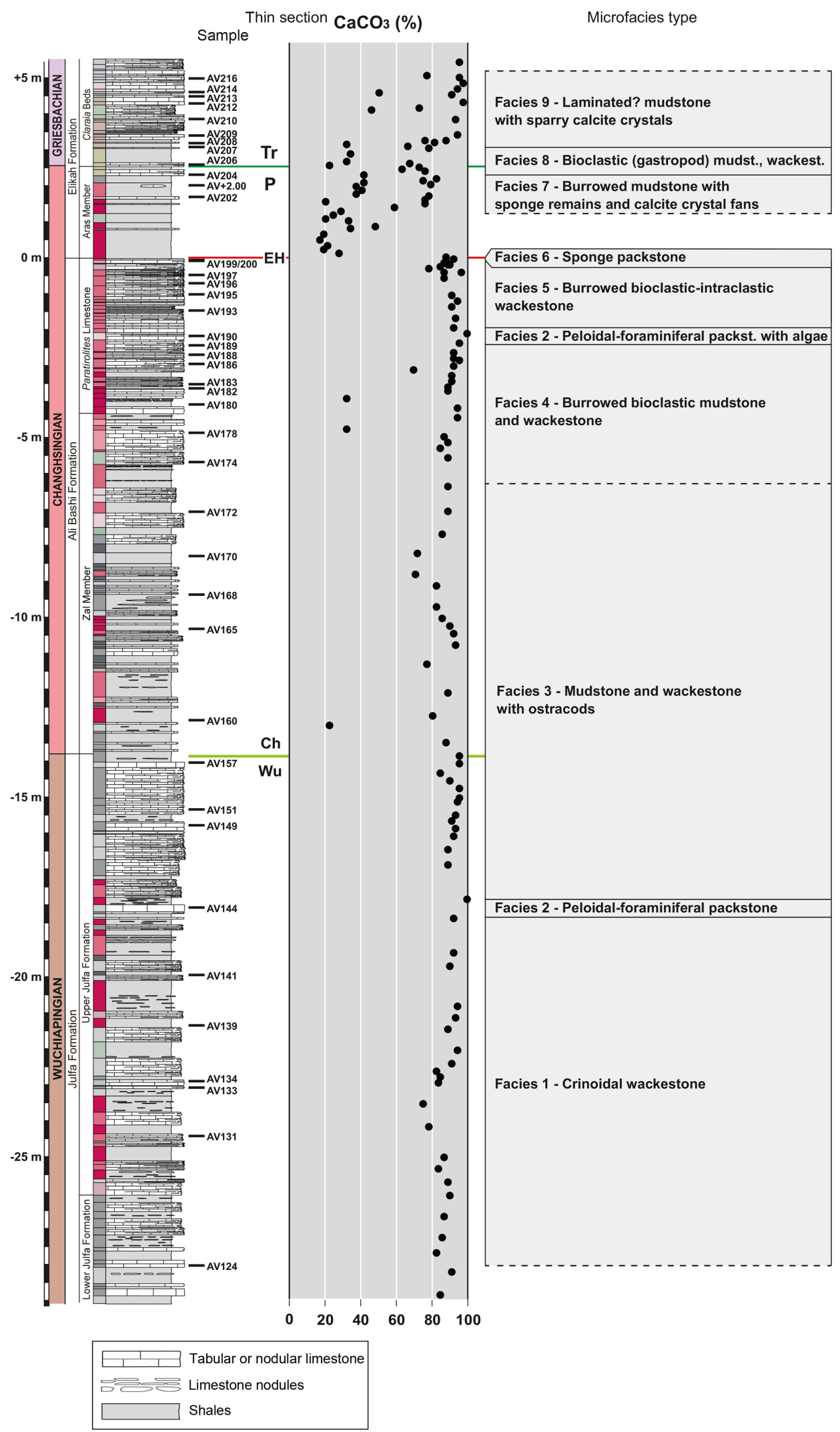

Figure 8. Microfacies types and carbonate content of samples from the Aras Valley section. Dashed lines indicate transitional microfacies change or possible continuation of the microfacies type. (Wu - Wuchiapingian; $\mathrm{Ch}$ - Changhsingian; EH - extinction horizon; P - Permian; $\operatorname{Tr}-$ Triassic). 
produced abiotically or biotically (Woods et al., 1999; Wignall and Twitchett, 2002; Heydari et al., 2003; Wignall et al., 2005; Leda et al., 2014; Friesenbichler et al., 2018). In contrast to the "digitate stromatolites" described by Friesenbichler et al. (2018), which are suggested to be of biotic origin, the crystal fans in the Aras Valley section do not show internal lamination. Therefore, we interpret these structures as abiotically formed aragonite crystals, induced by unusual water chemistry (i.e. supersaturated with respect to calcium carbonate), which were later recrystallized to calcite. An increase in total alkalinity, induced by intensified silicate weathering, a "carbonate overshoot" following an ocean acidification event or more passively through the extinction of many calcifying organisms, could have led to a supersaturation of ocean water with respect to calcium carbonate and consequently to the precipitation of the crystal fan structures (Zeebe and Westbroek, 2003; Knoll et al., 2011; Leda et al., 2014; Lehrmann et al., 2015; Foster et al., 2019, 2020). No sedimentary or palaeontological features indicative of shallow-water or high-energy conditions have been recognized in the deposits of the Aras Member in the Aras Valley. Therefore, we interpret that the Aras Member was deposited in an outer-shelf setting with low water energy, comparable to the depositional environment of the Paratirolites Limestone. Similar deep settings have been suggested for neighbouring sections such as Ali Bashi and Zal (e.g. Richoz et al., 2010; Leda et al., 2014). This contrasts with the interpretation of Mohtat Aghai et al. (2009), who postulated that the Boundary Clay was deposited in relatively shallow environments with quiet and stagnant waters, or with the interpretation of Heydari et al. (2003), who suggested a shallow environment based on geochemical data and on the occurrence of reefal and grainy facies coeval with synsedimentary carbonate cements studied in sections near Abadeh (central Iran).

The platy limestone beds of the basal Claraia Beds are mostly composed of mudstone and bindstone, which are poor in fossils and often partially recrystallized. The lowermost part consists of mud-supported facies (facies 8) with scarce fossils (i.e. high-spired microgastropods and ostracods), which are overlain by recrystallized mudstone and crudely laminated bindstone with sub-rounded sparry calcite crystals (facies 9). The occurrence of irregular lamination and clotted texture possibly indicates a microbial origin, but the poorly preserved fabric and the abundant chemical compaction features make any interpretation equivocal. No remains of microbial or algal structures have been recognized. Thus, the origin of these crystals remains unclear. Similar structures have also been observed in association with microbial mats or oncoids in other sections from the central and western Tethys (Hips and Haas, 2006; Richoz et al., 2010; Leda et al., 2014; Foster et al., 2020). Based on the similar morphology and size of the crystals and the skeletal grains, these sparry calcite crystals may be interpreted as recrystallized bioclasts (i.e. crinoids and/or microgastropods) trapped during the halt of the microbial mat growth. Alternatively, the crystals may represent calcified coccoidal remains as suggested by Hips and Haas (2006), but the size of the crystals from the Aras Valley section is much larger. The presence of this microbial facies may indicate an equivalent formation to basal Triassic microbialites. These microbial buildups, which are a typical feature in other Tethyan sections, e.g. in south China (Kershaw et al., 2007, 2012; Lehrmann et al., 2015; Bagherpour et al., 2017; Foster et al., 2020), Slovenia (Kolar-Jurkovšek et al., 2018; Foster et al., 2020), Turkey (Baud et al., 1997, 2005; Pruss et al., 2006; Richoz, 2006; Kershaw et al., 2007; Heindel et al., 2018; Foster et al., 2020), Armenia (Friesenbichler et al., 2018; Foster et al., 2020), and central Iran (Taraz et al., 1981; Heydari et al., 2003, 2008; Leda et al., 2014; Foster et al., 2020), are absent in the NW Iranian sections. The lack of clear sedimentary and palaeontological indicators for water depth and water energy in the deposits of the Claraia Beds hinders their palaeoenvironmental reconstruction. However, there are indications of a temporal shallowing-upward trend during this time in the neighbouring Ali Bashi and Zal sections (Leda et al., 2014), as suggested by the occurrence of oncoidal facies.

\section{Conodont stratigraphy}

For the study of the conodont succession, a total of 97 samples, each of about $2 \mathrm{~kg}$ weight, were processed following the standard protocol. The samples were dissolved using diluted acetic or formic acid, sieved with a $0.063 \mathrm{~mm}$ mesh, and the dry residue was then processed by magnetic separation.

The conodont biostratigraphy of the Late Permian sedimentary succession of Transcaucasia focused on the Ali Bashi sections (Sweet in Teichert et al., 1973) and the Dorasham sections (Kozur et al., 1978, 1980). Subsequently, Kozur (2004a, 2005) proposed a more precise resolution of these sections including 12 conodont biozones. A revision of this subdivision was suggested by Shen and Mei (2010); they proposed a zonal scheme with eight zones spanning the interval from the late Wuchiapingian $C$. orientalis zone to the latest Changhsingian C. hauschkei zone.

Ghaderi (2014), Ghaderi et al. (2014b), and Isaa et al. (2016) revised the conodont succession of the sections in the Julfa region. In these studies, the late Permian interval was subdivided into 16 conodont zones, of which six characterize the Wuchiapingian and 10 the Changhsingian (Fig. 9). In these studies, it was also shown as remarkable that the stratigraphic resolution increases towards the end of the Late Permian, as the rock intervals representing distinct conodont zones become thinner because of increased evolutionary rates of the genus Clarkina. The lower Julfa Formation, for instance, belongs to only one conodont zone $(C$. leveni zone), while the Paratirolites Limestone alone has six conodont zones. Only a part of this pattern may be caused 
by condensation of the uppermost beds of the Paratirolites Limestone.

The base of the Changhsingian stage in the NW Iranian sections was defined by Ghaderi et al. (2014b) with the $C$. orientalis-C. subcarinata interval zone, which was taken as equivalent to the absent basal Changhsingian conodont marker species $C$. wangi (Jin et al., 2001). The stage boundary is located close to the base of the Zal Member. The endPermian extinction horizon marks the boundary between the C. hauschkei and Hindeodus praeparvus $-H$. changxingensis zones. The upper limit of the Changhsingian is characterized by the first occurrence of $H$. parvus, which indicates the official Permian-Triassic boundary (Kozur, 2005, 2007b).

The conodont succession of the Aras Valley section in ascending order is as follows (Fig. 9; for representative species, see Figs. 10, 11).

1. Clarkina leveni interval zone. The lowermost logged and sampled part of the Aras Valley section with $3.30 \mathrm{~m}$ thickness belongs to the lower Julfa Formation and the C. leveni zone, which was recorded for the first time by Kozur (1975) in the Achura section of Transcaucasia. $C$. asymmetrica, $H$. minutus, and $H$. typicalis are the most common associated species.

2. Clarkina guangyuanensis interval zone. This interval zone was established by Mei et al. (1994) in the Dukou and Nanjing sections of Sichuan (south China). The first occurrence of the zonal species at the base and the first occurrence of $C$. transcaucasica at the top define the interval. The $C$. guangyuanensis interval zone, with $3.30 \mathrm{~m}$ thickness in the Aras Valley section, is the first conodont zone in the upper Julfa Formation. C. liangshanensis arises in the upper part of this zone; however, it ranges to the middle part of the $C$. orientalis zone; $H$. typicalis is another associated species.

3. Clarkina transcaucasica interval zone. As in the case of the previous zone, the $C$. transcaucasica zone was first defined by Mei et al. (1994) at Dukou and Nanjing in Sichuan. It comprises the interval from the first occurrence of $C$. transcaucasica up to the first occurrence of $C$. orientalis and comprises a thickness of $4.55 \mathrm{~m}$ in the Aras Valley section. C. liangshanensis and H. typicalis are co-occurring in the entire interval, while $C$. guangyuanensis is present in some of the lowest beds.

4. Clarkina orientalis range zone. This is the youngest conodont zone within the upper Julfa Formation. The zone was introduced by Kozur (1975) and is defined by the first occurrence of the zonal species; however, the position of its top is variable in different localities (Shen and Mei, 2010). For instance, the zone is overlain by the C. inflecta zone in the Dukou and Nanjing sections (Mei et al., 1994), but $C$. orientalis is still present in the $C$. inflecta zone. In the Meishan section (Zhejiang, south
China), it is followed by the $C$. longicuspidata zone, but $C$. orientalis ranges into the basal Changhsingian C. wangi zone (Mei et al., 1994; Jin et al., 1997). In the Aras Valley section, the $C$. orientalis zone has a thickness of $4.15 \mathrm{~m}$ and is completely restricted to the grey to beige nodular limestone of the uppermost Julfa Formation. Associated species in the $C$. orientalis zone are $C$. transcaucasica and $C$. liangshanensis, which are mostly common in the lower parts of this zone.

5. Clarkina orientalis-Clarkina subcarinata interval zone (Clarkina wangi zone). The zone is used here for the base of the Changhsingian stage in the NW Iranian sections. In the Aras Valley section, it is limited to the $1.65 \mathrm{~m}$ fossiliferous interval between the last occurrence of $C$. orientalis and the first occurrence of $C$. subcarinata (Ghaderi et al., 2014b). The zone is accompanied by the species of $H$. typicalis and the first occurrence of $H$. julfensis, with the latter mostly considered to be a Changhsingian hindeodid species (e.g. Metcalfe, 2012).

According to Kozur (2005), the $C$. orientalis zone is overlain by the "Dorashamian" (Changhsingian) $C$. hambastensis zone in Iran. However, C. hambastensis is limited to the sections in the Abadeh region and has never been recovered from the NW Iranian sections (Ghaderi, 2014) including the Aras Valley section. In the Meishan section of south China, the $C$. wangi zone was considered the first Changhsingian conodont zone by Mei et al. (2004). Neither Shen (2007) nor Shen and Mei (2010) strictly regarded the $C$. wangi zone as the overlaying biozone of the $C$. orientalis zone in Iran, but they did not present any evidence to confirm this claim. In our investigations, no trace of $C$. wangi and $C$. hambastensis could be found in the Aras Valley section or any other section of the Julfa region.

6. Clarkina subcarinata interval zone. The nominal species was coined by Sweet in Teichert et al. (1973) as the subspecies Neogondolella carinata subcarinata and amended by Mei et al. (1998b) as $C$. subcarinata. This biozone has a thickness of $4.58 \mathrm{~m}$ in the Aras Valley section and is here the thickest Changhsingian biozone. Its upper boundary is limited to the first occurrence of $C$. changxingensis. H. typicalis and $H$. julfensis are associated species.

7. Clarkina changxingensis interval zone. The first occurrence of $C$. changxingensis indicates the zone base and the first occurrence of $C$. bachmanni validates its top. Kozur (2005) stated that $C$. bachmanni follows the $C$. subcarinata zone and $C$. changxingensis occurs in association with $C$. deflecta in an assemblage zone above the C. nodosa zone. This cannot be confirmed and the actual position of the $C$. changxingensis zone, as Shen and Mei (2010) and Ghaderi et al. (2014b) demonstrated, is 


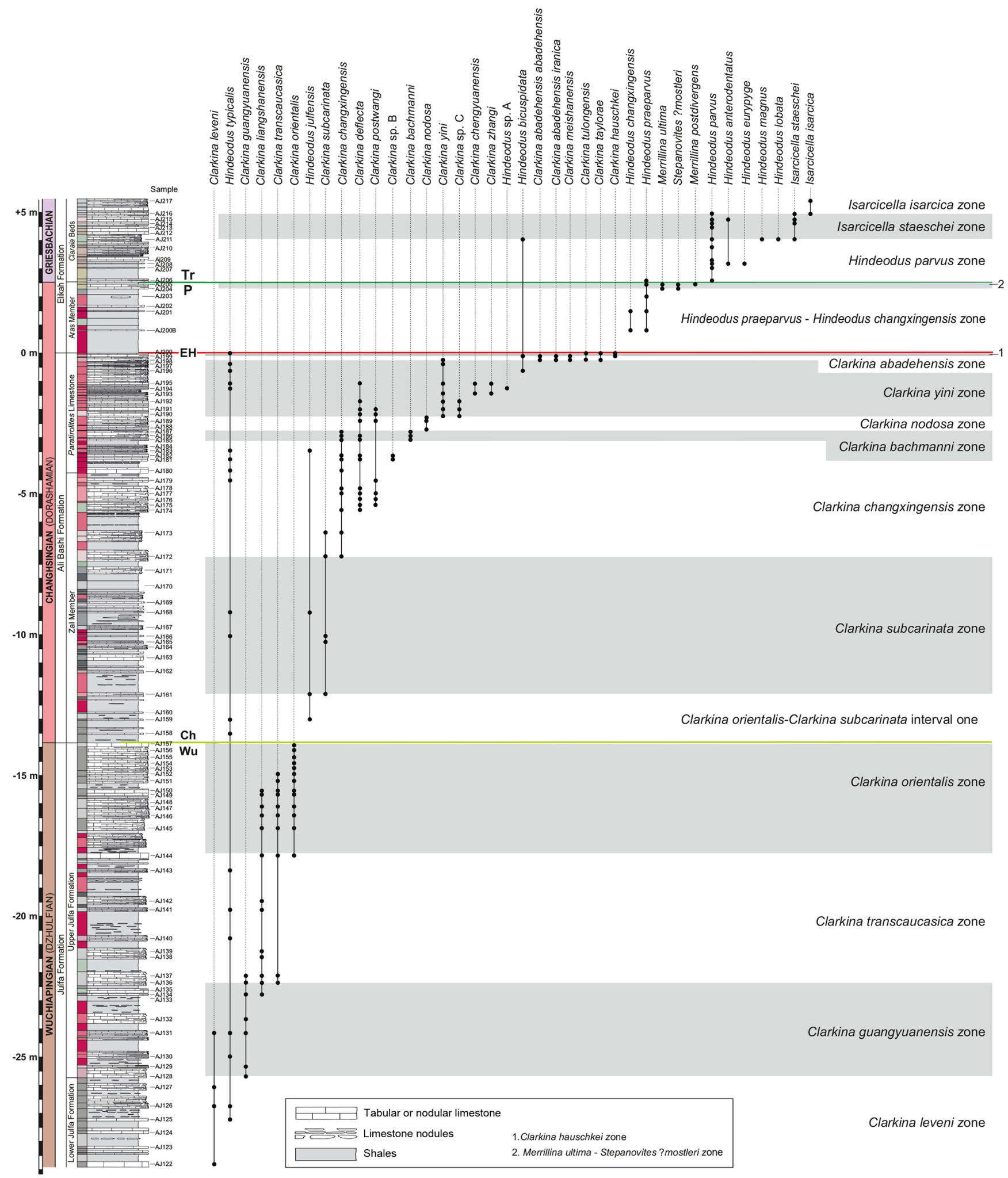

Figure 9. Succession of conodont species and zones in the Aras Valley section. (Wu - Wuchiapingian; $\mathrm{Ch}-\mathrm{Changhsingian;} \mathrm{EH} \mathrm{-} \mathrm{extinction}$ horizon; P - Permian; Tr - Triassic). 


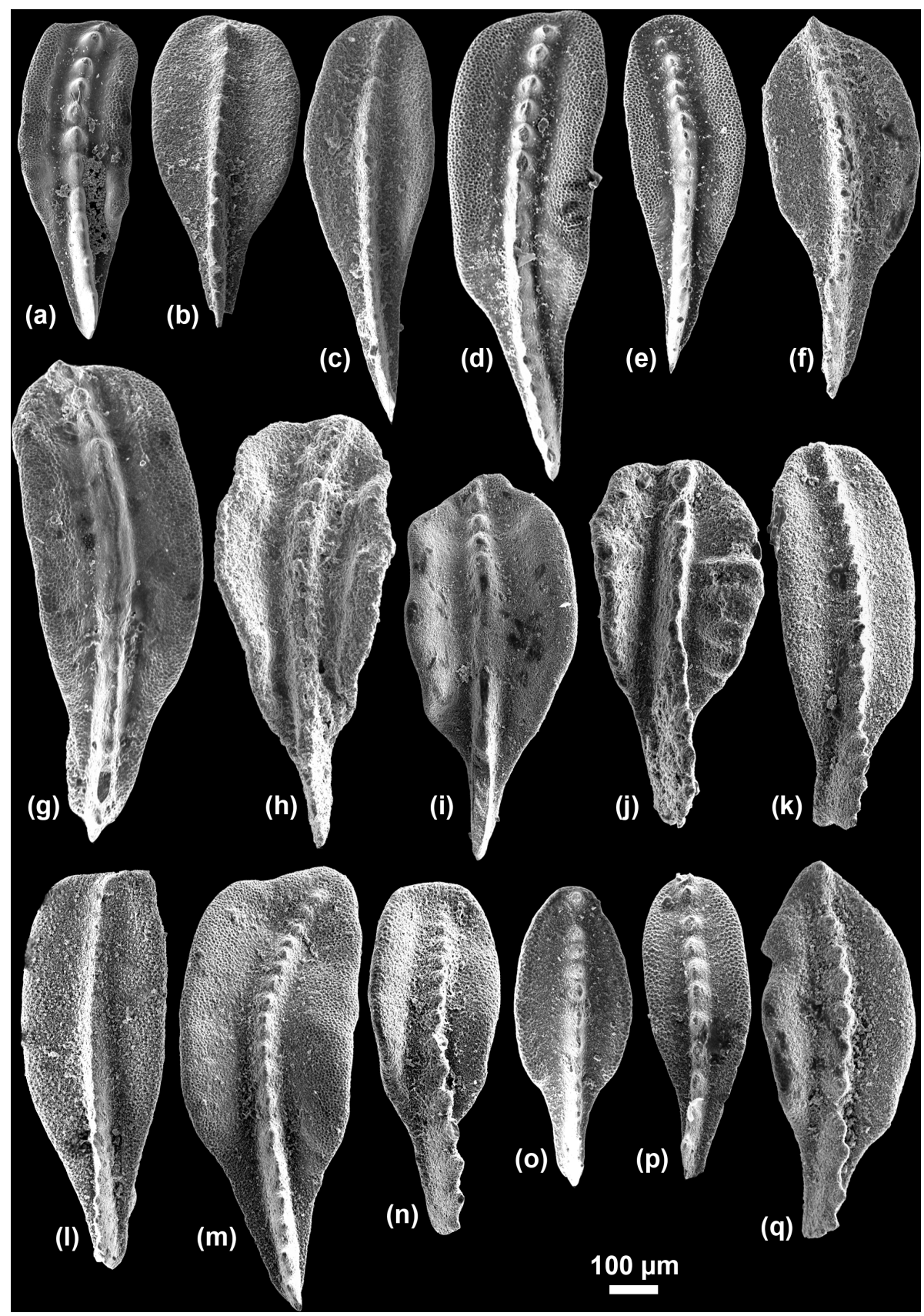

Figure 10. Characteristic conodonts from the Aras Valley section (scale bars equal to $100 \mu \mathrm{m}$ ); all specimens stored in the collection of the Ferdowsi University, Mashhad. (a) Clarkina leveni Kozur et al., 1975, FUM no. AJ122-1, lower Julfa Formation, upper view; (b) Clarkina guangyuanensis Dai and Zhang in (Li et al., 1989), FUM no. AJ131-7, upper Julfa Formation, upper view; (c) Clarkina liangshanensis (Wang, 1978), FUM no. AJ179-8, upper Julfa Formation, upper view; (d) Clarkina transcaucasica (Gullo and Kozur, 1992), FUM no. AJ151-5, upper Julfa Formation, upper view; (e) Clarkina orientalis (Barskov and Koroleva, 1970), FUM no. AJ157-9, upper Julfa Formation , upper view; (f) Clarkina changxingensis (Wang and Wang in Zhao et al., 1981b), FUM no. AJ173-1, Ali Bashi Formation, Zal Member, upper view; (g) Clarkina subcarinata (Sweet in Teichert et al., 1973), FUM no. AJ165-7, Ali Bashi Formation, Zal Member, upper view; (h) Clarkina deflecta (Wang and Wang, 1981a), FUM no. AJ177-14, Ali Bashi Formation, Paratirolites Limestone, upper view; (i) Clarkina bachmanni Kozur, 2004, FUM no. AJ185-23, Ali Bashi Formation, Paratirolites Limestone, upper view; (j) Clarkina nodosa Kozur, 2004, FUM no. AJ190-7, Ali Bashi Formation, Paratirolites Limestone, upper view; (k) Clarkina yini Mei, 1998b, FUM no. AJ192-5, Ali Bashi Formation, Paratirolites Limestone, upper view; (l) Clarkina tulongensis (Tian, 1982), FUM no. AJ198-4, Ali Bashi Formation, Paratirolites Limestone, upper view; (m) Clarkina abadehensis abadehensis Ghaderi, 2014, FUM no. AJ198-13, Ali Bashi Formation, Paratirolites Limestone, upper view; (n) Clarkina abadehensis iranica Ghaderi, 2014, FUM no. AJ198-9, Ali Bashi Formation, Paratirolites Limestone, upper view; (o) Clarkina hauschkei Kozur, 2004, FUM no. AJ200-77, Ali Bashi Formation, Paratirolites Limestone, upper view; (p) Clarkina taylorae (Orchard et al., 1994), FUM no. AJ198-21, Ali Bashi Formation, Paratirolites Limestone, upper view; (q) Clarkina cf. chengyuanensis, FUM no. AJI195-23, Ali Bashi Formation, Paratirolites Limestone, upper view. 


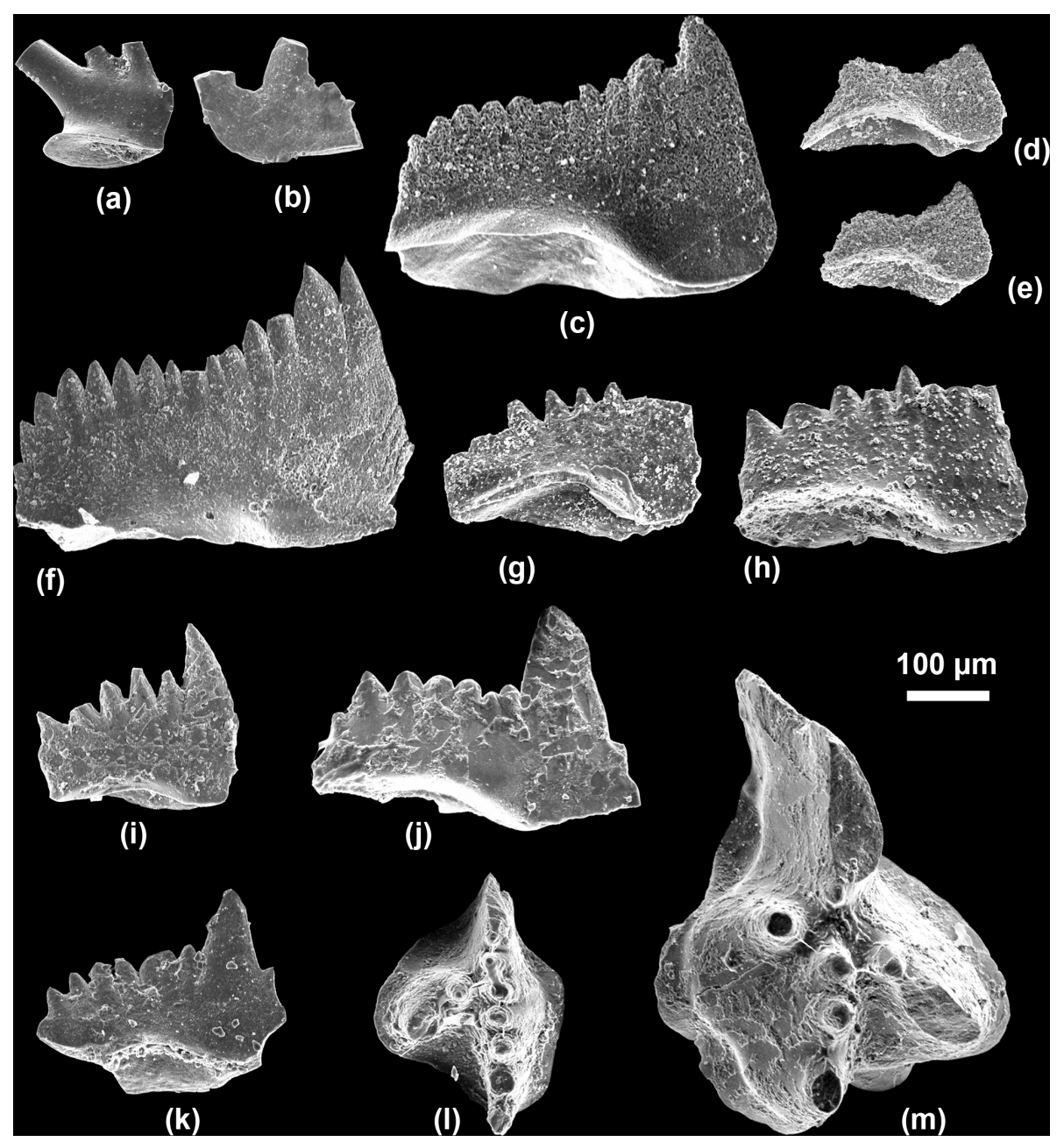

Figure 11. Characteristic conodonts from the Aras Valley section (scale bars equal to $100 \mu \mathrm{m}$ ); all specimens stored in the collection of the Ferdowsi University, Mashhad. (a) Merrillina ultima Kozur, 2004, Pa element, FUM no. AJ204.13, Elikah Formation, Aras Member, lateral view; (b) Stepanovites sp., Sc element, FUM no. AJ205-1, Elikah Formation, Aras Member, lateral view; (c) Hindeodus typicalis (Sweet, 1970), FUM no. AJ200-27, Ali Bashi Formation, Paratirolites Limestone, lateral view; (d) Hindeodus julfensis (Sweet, in Teichert et al., 1973), FUM no. AJ183-8, Ali Bashi Formation, Paratirolites Limestone, lateral view; (e) Hindeodus julfensis (Sweet, in Teichert et al., 1973), FUM no. AJ183-5, Ali Bashi Formation, Paratirolites Limestone, lateral view; (f) Hindeodus bicuspidatus Kozur, 2004, FUM no. AJ200-32, Ali Bashi Formation, Paratirolites Limestone, lateral view; (g) Hindeodus praeparvus Kozur, 1996, FUM no. AJ201-4, Elikah Formation, Aras Member, lateral view; (h) Hindeodus eurypyge Nicoll et al., 2002, FUM no. AJ208-2, Elikah Formation, Aras Member, lateral view; (i) Hindeodus parvus (Kozur and Pjatakova, 1976), FUM no. AJ206-2, Elikah Formation, Aras Member, lateral view; (j) Hindeodus magnus Kozur, 2004, FUM no. AJ211-15, Elikah Formation, Claraia Beds, lateral view; (k) Hindeodus anterodentatus (Dai et al., 1989), FUM no. AJ208-7, Elikah Formation, Aras Member, lateral view; (l) Isarcicella staeschei Dai \& Zhang, 1989, FUM no. AJ216-2, Elikah Formation, Claraia Beds, upper view; (m) Isarcicella isarcica (Huckriede, 1958), FUM no. AJ217-13, Elikah Formation, Claraia Beds, upper view.

immediately above the $C$. subcarinata zone. Accompanying species in the $C$. changxingensis interval zone are C. subcarinata, C. deflecta, C. postwangi, H. typicalis, and $H$. julfensis, of which $C$. subcarinata and $H$. julfensis show their last occurrences here. The $C$. changxingensis zone has a thickness of $4.30 \mathrm{~m}$ in the Aras Valley section, and the lithological boundary of the Zal Member and Paratirolites Limestone is located within the zone.
8. Clarkina bachmanni range zone. This zone was firstly described by Kozur (2005) for the Changhsingian sections of Iran. The zone is defined by the total range of $C$. bachmanni which overlays the significant presence of hindeodids on top of the previous $C$. changxingensis zone. According to Chen et al. (2008), C. bachmanni represents transitional morphotypes between the round and narrow ones. C. changxingensis and C. de- 
flecta are associated species and the zonal thickness is only $0.38 \mathrm{~m}$.

9. Clarkina nodosa range zone. This zone was established by Kozur (2005) as a total range zone of the naming species $C$. nodosa. It has a thickness of $0.50 \mathrm{~m}$ in the Aras Valley section; associated species are $C$. postwangi and $C$. deflecta.

10. Clarkina yini interval zone. In the Changhsingian stratotype section in Meishan (south China), this biozone comfortably overlays the $C$. changxingensis zone and is overlain by the C. meishanensis zone (Mei et al., 1998a; Yuan et al., 2014). In contrast, the sections in NW Iran show biozones between these two zones; they are defined by $C$. bachmanni and C. nodosa. The $C$. yini zonal base is characterized by the first occurrence of $C$. yini, and in the Aras Valley section the first occurrence of this species is in the pink key limestone in the middle part of the Paratirolites Limestone. C. postwangi, C. deflecta, $C$. chengyuanensis, $C$. zhangi (sensu Kozur), $H$. bicuspidata, and H. typicalis are the most important accompanying taxa. The thickness of the $C$. yini zone in the Aras valley section is $1.95 \mathrm{~m}$.

11. Clarkina abadehensis range zone. An equivalent was introduced as the Clarkina iranica zone by Kozur (2005), but Shen and Mei amended the species to C. abadehensis. According to Ghaderi et al. (2014b) the biozone comprises the whole range of $C$. abadehensis (with both the supposed subspecies $C$. abadehensis abadehensis and $C$. abadehensis iranica). Associated species of this biozone are $C$. meishanensis, $C$. tulongensis, $C$. taylorae, and $H$. bicuspidata. It is only $0.18 \mathrm{~m}$ thick in the Aras Valley section.

12. Clarkina hauschkei range zone. This is the topmost conodont zone in the Ali Bashi Formation; it comprises only the top $0.13 \mathrm{~m}$ of the Paratirolites Limestone up to the extinction horizon. The $C$. hauschkei range zone was firstly defined by Kozur (2005) based on the full range of the nominal species and shows the occurrence of the two subspecies of $C$. meishanensis meishanensis and $C$. meishanensis zhangi. In addition, $C$. tulongensis and $C$. taylorae are present in this biozone. It is the thinnest of the conodont zones in the section.

13. Hindeodus praeparvus-Hindeodus changxingensis assemblage zone. Kozur (2005) defined, at the base of the Aras Member, an assemblage zone equivalent to the $C$. meishanensis $-H$. praeparvus zone. This biozone thus immediately overlays the mass extinction horizon. Notwithstanding, C. meishanensis, which is already present at the base of the $C$. hauschkei zone, is very rare at the top of the Paratirolites Limestone in the NW Iranian sections. In the Aras Valley section, this species is completely absent in the Aras Member. In contrast, $H$. changxingensis, which first occurs in the lowest samples of the Aras Member in all of the sections, is very abundant. Therefore, Ghaderi et al. (2014b) suggested the introduction of the $H$. praeparvus $-H$. changxingensis assemblage zone as a replacement of the $C$. meishanensis$H$. praeparvus zone of Kozur (2005). The thickness of this biozone is $2.30 \mathrm{~m}$ in the Aras Valley section.

14. Merrillina ultima-Stepanovites mostleri assemblage zone. In the Aras Valley section, this biozone contains ramiform elements of Merrilina ultima and Stepanovites mostleri in association with $H$. praeparvus and rare Merrilina postdivergens. The biozone was firstly established by Kozur (2005); it is considered to be correlated with the $C$. zhejiangensis zone of Mei et al. (1998a) in the Meishan section (Kozur, 2005). In agreement with the previous studies by Ghaderi et al. (2014b), the presence of this biozone with $0.25 \mathrm{~m}$ thickness is confirmed here in the Aras Valley section.

15. Hindeodus parvus interval zone. The base of this biozone is defined by the first occurrence of $H$. parvus and marks the beginning of the Triassic system (Yin et al., 2001). This key level is situated at a position of $+2.55 \mathrm{~m}$ in the Aras Valley section; the biozone has a thickness of $1.55 \mathrm{~m}$. Accompanying species within this biozone are $H$. anterodentatus and $H$. eurypyge.

16. Isarcicella staeschei interval zone. This biozone is defined by the first occurrence of I. staeschei (Wang, 1996; Wang and Wang, 1997). It is $0.85 \mathrm{~m}$ thick in the studied section. $H$. parvus and $H$. anterodentatus accompany the nominal species.

17. Isarcicella isarcica zone. The first occurrence of $I$. isarcica is the marker for definition of another conodont zone on top of the I. staeschei interval zone (Wang and Wang, 1997; Perri and Farabegoli, 2003). The I. isarcica zone in the Aras Valley section continues till the end of the logged section and thus has at least $2 \mathrm{~m}$ thickness.

\section{Ostracod succession}

The Aras Valley section was sampled for ostracods from -3.80 to $+7.00 \mathrm{~m}$ with respect to the extinction horizon; this covers almost the entire Paratirolites Limestone, the Aras Member, and the lower part of the Claraia Beds. In total 59 samples were taken for subsequent processing. The limestone samples (around $400 \mathrm{~g}$ each) were processed by hot acetolysis as described in Crasquin et al. (2005). The clay material $(1 \mathrm{~kg}$ each) from the Aras Member was treated with water and, in some cases where it was necessary, with tensides and was subsequently wet sieved. For the sieving processes we used two sieves with mesh widths of 0.063 and $1.5 \mathrm{~mm}$ 
The ostracod taxonomy of the nearby Dorasham II section was already investigated by Belousova (1965); her study comprised 500 late Wuchiapingian to late Changhsingian specimens of 26 species. Belousova showed that there was a gradual taxonomic change between the assemblages with a relatively constant diversity. However, Belousova (1965) and the subsequent investigation by Kotlyar et al. (1983), who described a less diverse assemblage from the Paratirolites Limestone, only described the succession below the extinction horizon, not allowing any investigation of the extinction event itself.

Ostracods were present in all 59 samples. The abundances of ostracods through the studied interval range between four and approximately 31500 specimens per $500 \mathrm{~g}$ of sample material (Fig. 12). In total, 3428 specimens were identified at the species level. A total of 62 species are present, belonging to 23 genera and 12 families (Fig. 13). The three sampled lithological units show the following characteristics in terms of abundance, diversity, and taxonomic patterns.

1. Paratirolites Limestone. Most of the Paratirolites Limestone samples show specimen numbers between 200 and 300, but higher occurrences reach up to 700 specimens. The diversity is generally low with only four species in most of the sample horizons; however, it reaches eight species at $-0.40 \mathrm{~m}$ in the section. The highest Paratirolites limestone sample at $-0.01 \mathrm{~m}$, corresponding to the sponge-rich layer, yielded a monospecific assemblage, consisting exclusively of Fabalicypris obunca Belousova, 1965.

The assemblages of the Paratirolites Limestone are mainly composed of specimens of the order Podocopida, generally dominated by the genus Fabalicypris (Fig. 121-m). The most common species in this preextinction interval is Fabalicypris obunca. Hungaroleberis sp. nov. (Fig. 12o) as the only myodocopid species in the section is the only exception among the predominant podocopid species and occurs in the interval from -3.30 to $-1.40 \mathrm{~m}$.

2. Aras Member. The abundance distribution in the Aras Member is very heterogeneous, ranging from 6 to 31500 specimens per $500 \mathrm{~g}$ of sample material. The samples between +0.45 and $+0.75 \mathrm{~m}$ and at $+1.25 \mathrm{~m}$ are marked by very low values of 6 to 46 specimens. Higher up in the section, at $+1.71 \mathrm{~m}$, there is a characteristic shale layer with ostracod mass occurrences of around 31500 specimens per $500 \mathrm{~g}$ (Fig. 14). Species richness is increasing in the Aras Member, starting just above the extinction horizon and reaching its maximum of 16 at $+1.16 \mathrm{~m}$ in the section. A subsequent diversity drop to four species occurs at $+1.71 \mathrm{~m}$ and is followed by an increase that extends up to the overlying Claraia Beds.
The first diversity increase, which begins immediately above the extinction level, is paralleled by a complete faunal turnover (Fig. 13). The poorly diverse Fabalicypris-dominated community of the Paratirolites Limestone was replaced by a relatively diverse Bairdiacypris-dominated community. This faunal turnover takes place at the transition from the Paratirolites Limestone to the Aras Member. The nearby Zal section, which was studied by Mette (2008, 2010), records a similar pattern of complete faunal turnover with the first deposition of the Boundary Clay, with the crucial difference that the assemblage of the Aras Member in the succession of Zal is of low diversity and dominated by a single species of the genus Indivisia. In contrast, in the Aras Valley section, the lower to middle part of the Aras Member yielded a diverse assemblage, consisting of mainly Bairdiacypris ottomanensis CrasquinSoleau, 2004, but also of species of the orders Platycopida and Palaeocopida, such as species of Cavellina and Carinaknightina (Fig. 12g, j, k).

At $+1.71 \mathrm{~m}$, the Aras Member is marked by a bed with mass occurrences of ostracods, in particular of Bairdiacypris ottomanensis (Figs. 12b, 14). Despite very high abundances of around 31500 specimens per $500 \mathrm{~g}$, the assemblage shows a low diversity. B. ottomanensis is well-known from other late Permian to Early Triassic sedimentary successions in north-western and central Iran (Kozur, 2005; Mette, 2008, 2010; Forel et al., 2015), Turkey (Crasquin-Soleau et al., 2004a, b; Forel, 2014), and China (Crasquin-Soleau and Kershaw, 2005; Forel et al., 2009; Forel, 2012). Because of its cosmopolitan distribution and its high abundances in postextinction sediments in NW Iran, this species was referred to as a "disaster taxon" (Mette, 2010).

3. Claraia Beds. The lower $70 \mathrm{~cm}$ of the Claraia Beds shows relatively high abundances of about 1000 to 2500 specimens per $500 \mathrm{~g}$ sampled material, but higher samples are characterized by very low abundances that do not exceed 40 specimens. The accompanying diversity records a peak of 15 species at $+2.65 \mathrm{~m}$, followed by decreases in higher beds (from $+3.10 \mathrm{~m}$ ) to values between two and eight species per sample horizon. Up to around $+6.05 \mathrm{~m}$ in the section, the assemblages are dominated by $B$. ottomanensis. In the uppermost sample $(+7.00 \mathrm{~m})$, the taxonomic composition changes completely. In this sample, the specimens are mainly represented by a species of Bairdia together with Liuzhinia (Fig. 12c) and only one specimen of B. ottomanensis.

Most of the investigated ostracods from the Aras Valley are smooth-shelled species of the family Bairdiidae. The same pattern was found at the nearby Dorasham II section, where the majority of the 26 identified species also belong to the Bairdiidae (Belousova, 1965). In general, the occurrences of Bairdiidae are considered to indicate 


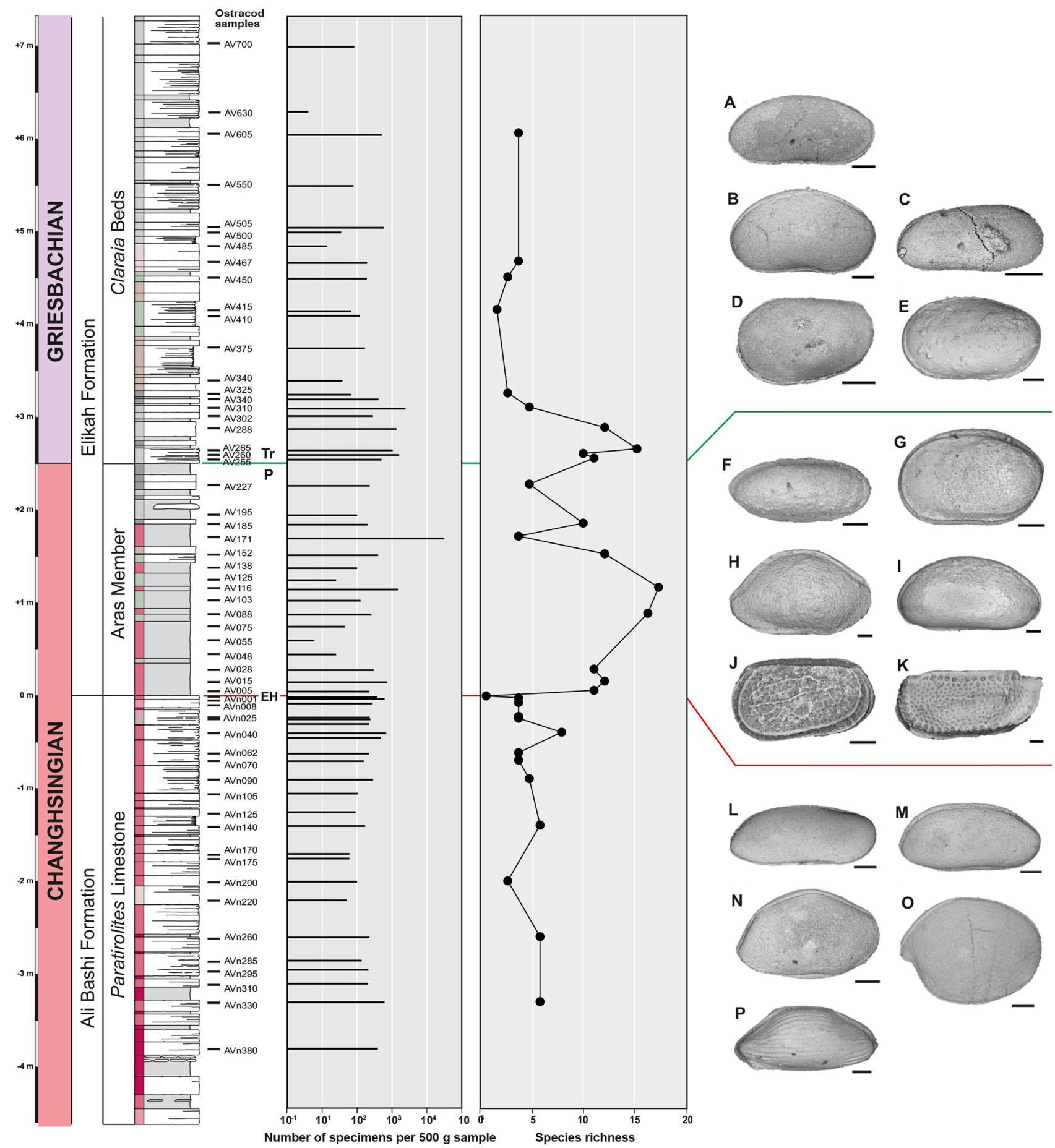

Figure 12. Quantity of ostracod specimens per $500 \mathrm{~g}$ of rock material and species richness in the Paratirolites Limestone, the Aras Member, and the Claraia Beds of the Aras Valley section and important ostracod species in the lithological units. Scale bar for figured ostracods $=100 \mu \mathrm{m}$. Figured ostracods are as follows. (a) Bairdia kemerensis Crasquin-Soleau, 2004. (b) Bairdiacypris ottomanensis CrasquinSoleau, 2004. (c) Liuzhinia sp. 2. (d) Langdaia sp. (e) Cavellina sp. (f) Microcheilinella sp. (g) Cavellina sp. nov. (h) Kempfina qinglaii (Crasquin), 2008. (i) Fabalicypris sp. nov. (j) Carinaknightina sp. nov. (k) Iranokirkbya brandneri Kozur and Mette, 2006. (l) Fabalicypris obunca Belousova, 1965. (m) Fabalicypris blumenstengeli Crasquin, 2008. (n) Orthobairdia sp. nov. (o) Hungaroleberis sp. nov. (p) gen. nov. sp. nov. 


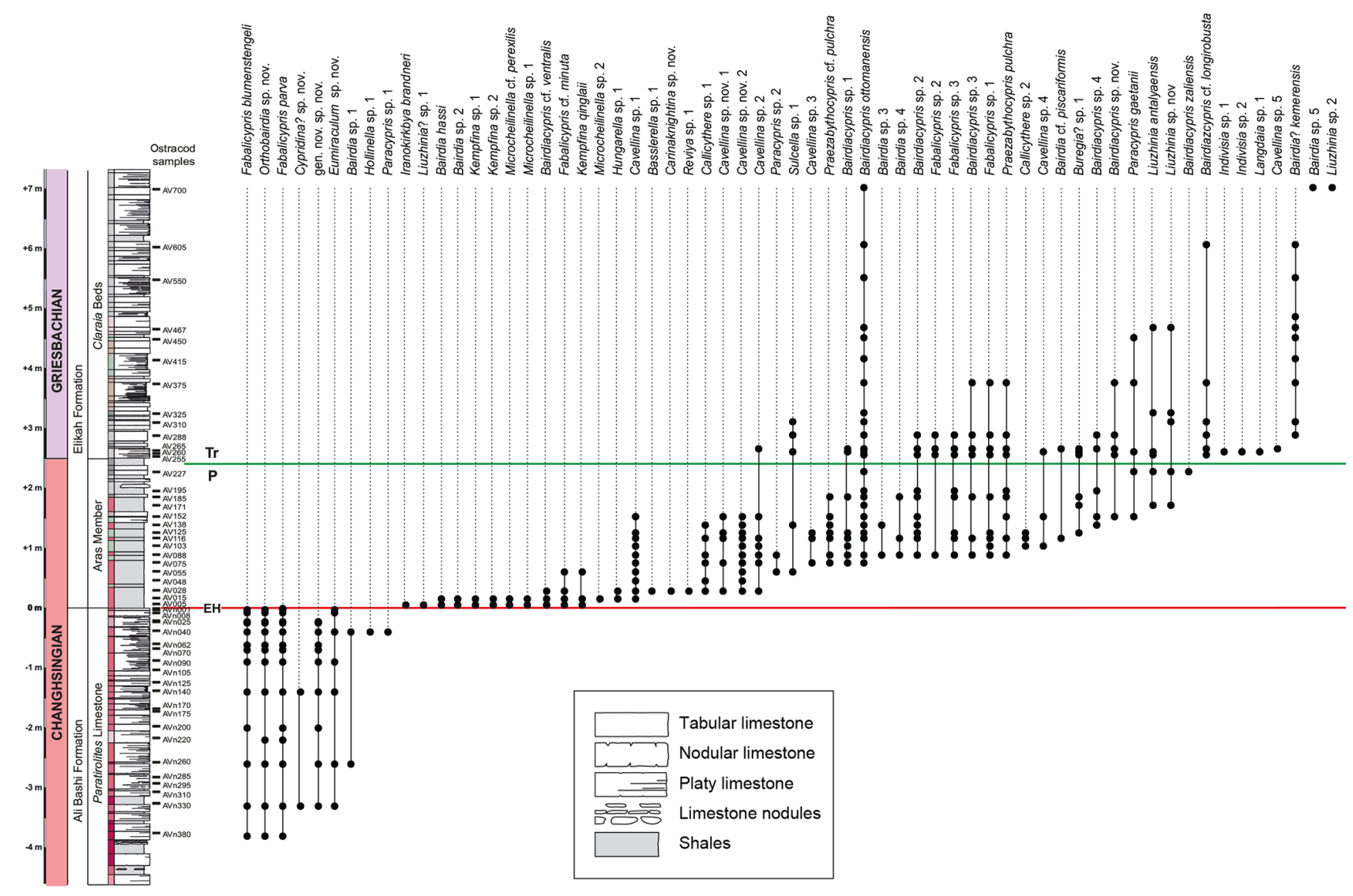

Figure 13. Succession of ostracod species in the Paratirolites Limestone, Aras Member, and Claraia Beds of the Aras Valley section.

normal, oxygenated, open marine conditions (Melnyk and Maddocks, 1988; Crasquin-Soleau et al., 1999).

\section{Ammonoid stratigraphy}

The Aras Valley section is the NW Iranian section that has yielded the most diverse ammonoid assemblages to date (Fig. 15). However, the abundance of specimens varies strikingly between the section intervals. While the Julfa Formation is rather poor in specimens, their number increases in the Zal Member, and finally the Paratirolites Limestone is comparatively rich in ammonoids.

A scheme for the biostratigraphic subdivision based on ammonoids of the Permian-Triassic boundary beds in the area of Julfa was proposed by Ruzhencev and Shevyrev (1965). They separated seven units (of which the upper four were, by Ruzhencev and Shevyrev, placed into the Triassic) now regarded as representing the Wuchiapingian and Changhsingian, in ascending order by the genera Araxoceras, Vedioceras, Phisonites, Tompophiceras, Dzhulfites, Bernhardites, and Paratirolites. Kotlyar et al. (1983) used these genera, after a revision by Teichert et al. (1973) and named biozones, from bottom to top with the species Arax-

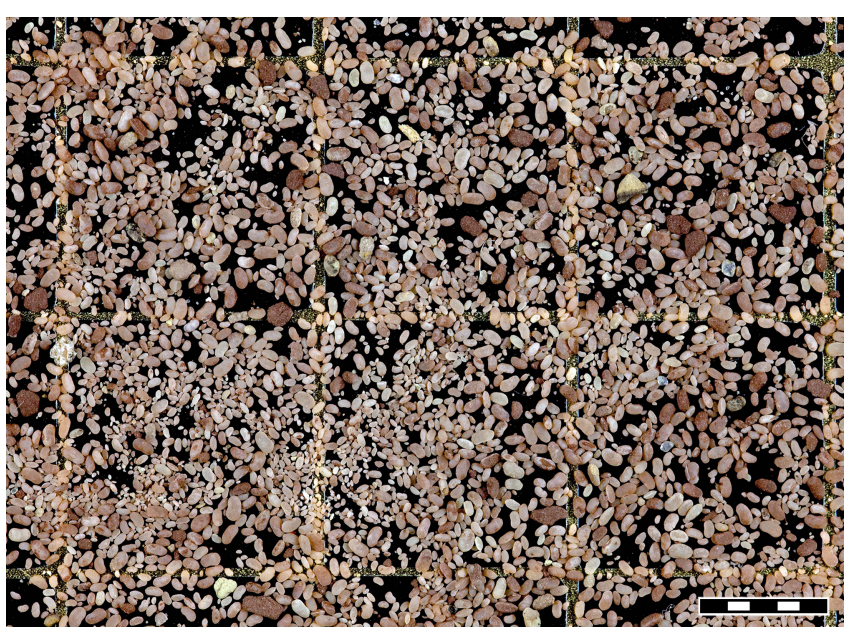

Figure 14. Mass occurrence of ostracod specimens in sample AV171 $(+1.71 \mathrm{~m})$. Scale bar units $=1 \mathrm{~mm}$. 


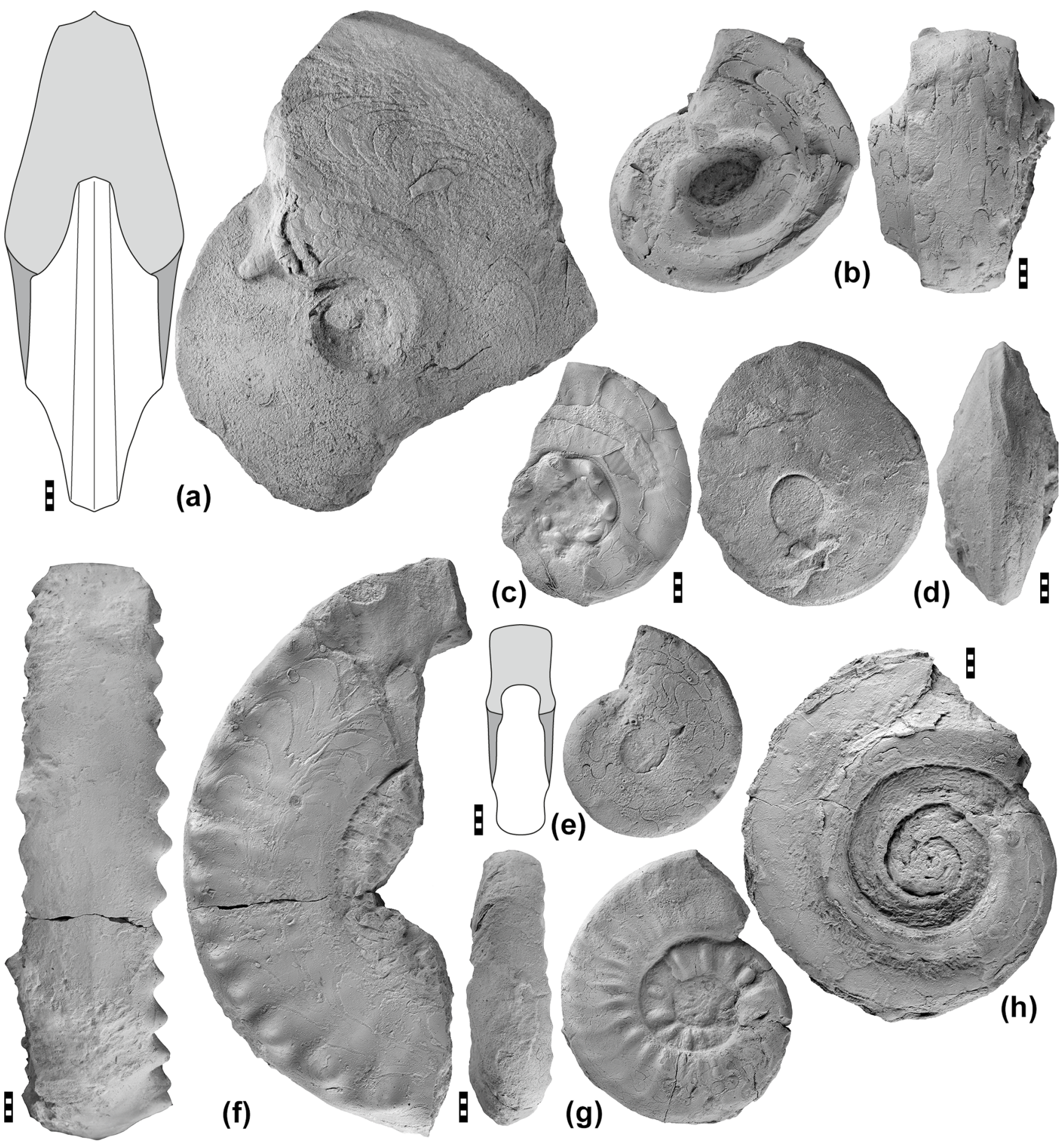

Figure 15. Selected representatives of ammonoids from the Aras Valley section. (a) Prototoceras discoidale Ruzhencev, 1963, specimen MB.C.29343 from the lower Julfa Formation. (b) Vedioceras fusiforme Korn \& Ghaderi, 2019, holotype MB.C.29132 from the upper Julfa Formation. (c) Iranites transcaucasius (Shevyrev, 1965), specimen MB.C.29148 from the Zal Member. (d) Pseudotoceras sp., specimen MB.C.29344 from the lower Julfa Formation. (e) Dzhulfoceras sp., specimen MB.C.29345 from the upper Julfa Formation. (f) Dzhulfites nodosus Shevyrev, 1965, specimen MB.C.29182 from the Zal Member at $-9.50 \mathrm{~m}$. (g) Araxoceltites cristatus Korn, Ghaderi and Ghanizadeh Tabrizi, 2019, holotype MB.C.22706 from the Zal Member. (h) Phisonites triangulus Shevyrev, 1965, specimen MB.C.22703 from the Zal Member at $-12.90 \mathrm{~m}$. 
oceras latissimum, Vedioceras ventrosulcatum, Phisonites triangulus, Iranites transcaucasinus, Dzhulfites spinosus, Shevyrevites shevyrevi, and Paratirolites kittli. Kotlyar et al. (1989) and Zakharov (1992) added another ammonoid zone at the top, the Pleuronodoceras occidentale zone; this zone should be represented in the lowest $2 \mathrm{~m}$ of the "lower Karabaglyar Formation", corresponding to the Aras Member of the Elikah Formation.

This general scheme of ammonoid stratigraphy can also be applied in the Aras Valley section, but as Ghaderi et al. (2014b) and Korn et al. (2016) have shown, the ammonoids of the Paratirolites Limestone do not represent only one single zone (Paratirolites kittli zone) but a succession of clearly separable units. By contrast, Leonova (2016), in her review on the Permian ammonoid stratigraphy, proposed a much less detailed zonation for the late Permian ammonoid succession. She only accepted three global ammonoid zones for the Changhsingian, the Phisonites triangulus zone, Paratirolites kittli zone, and Pleuronodoceras multinodosum-Rotodiscoceras asiaticum zone. This is remarkable in two aspects. (1) It neglects the rapid turnover rates of the ammonoid genera and species, as demonstrated by empirical data from the Julfa region (e.g. Ruzhencev and Shevyrev, 1965; Kotlyar et al., 1983; Ghaderi et al., 2014b; Korn et al., 2016, 2019a). (2) It accepts the previous assumption by Zhao et al. (1978) that the Transcaucasian genus Paratirolites is stratigraphically older than the south Chinese genera Pleuronodoceras and Rotodiscoceras. As Korn et al. (2016) pointed out, such an assumption was probably based on misidentification of specimens from south China as belonging to Paratirolites by Zhao et al. (1978).

From Aras Valley, more than 200 ammonoid specimens are available for study, of which the majority are from the Paratirolites Limestone. Because of the scarcity of ammonoids in the Wuchiapingian part of the section, most of the material from this interval was not collected in situ but from float and can thus only roughly be attributed to distinct rock units. The following ammonoid units can be separated in the Aras Valley section (Fig. 16).

Lower Julfa Formation (Araxoceras beds). Apart from the goniatite Pseudogastrioceras, the araxoceratid genera Araxoceras, Prototoceras and Vescotoceras are most common. With this composition, the Aras Valley section complements the neighbouring Dorasham II section (Ruzhencev and Shevyrev, 1965), but the number of specimens appears to be lower.

Upper Julfa Formation (Vedioceras beds). Most common is Pseudogastrioceras, which is accompanied by the genera Vedioceras, Pseudotoceras, and Vescotoceras. Ammonoids were found in situ at -25.05 (Vedioceras), $-22.40 \mathrm{~m}$ (Pseudogastrioceras, Vedioceras, Pseudotoceras), and $-14.20 \mathrm{~m}$ (Dzhulfoceras).

Zal Member (Iranites transcaucasinus-Phisonites triangulus zone to Shevyrevites shevyrevi zone). The ammonoids of this member from NW Iran have been monographically described by Korn et al. (2019a), including specimens from the Aras Valley section. Phisonites triangulus occurs in a single platy and marly limestone bed near the base of the Zal Member at $-12.90 \mathrm{~m}$. It is accompanied by poorly preserved specimens of Xenodiscus dorashamensis. As Ghaderi et al. (2014b) figured out, Iranites transcaucasinus occurs already below at $-13.50 \mathrm{~m}$, and hence the two zones separated by Ruzhencev and Shevyrev (1965) need to be merged.

The Dzhulfites nodosus zone is recorded, in the Aras Valley section, with the two species Dzhulfites nodosus and $D$. spinosus, which first occur at $-9.50 \mathrm{~m}$. A second horizon in the Aras section lies at $-8.20 \mathrm{~m}$, where Pseudogastrioceras relicuum occurs with specimens of Dzhulfites. Higher horizons with Dzhulfites occur at -7.60 and $-6.15 \mathrm{~m}$. The zone is thus rather well-represented in the Aras section, although the diversity is, with a total of five species, still rather low.

In the Aras section, the Shevyrevites shevyrevi zone is best seen in a rather fossiliferous purple shale package about $0.80 \mathrm{~m}$ below the base of the Paratirolites Limestone at $-5.40 \mathrm{~m}$. Unfortunately, the ammonoid specimens are mostly fragmented in this bed and only rarely allow the study of more than one volution. Araxoceltites cristatus is by far the most common taxon; it is accompanied by specimens of Shevyrevites and rare Dzhulfites (Korn et al., 2019a). Shevyrevites has obviously only a very limited stratigraphic range and characterizes only this thin interval at the top of the Zal Member below the Paratirolites Limestone.

Paratirolites Limestone. The ammonoid succession of the Paratirolites Limestone was outlined in detail by Korn et al. (2016). A total of 140 specimens were then available from the Aras Valley section; 90 of these were collected in situ with precise distance from the extinction horizon. Eight ammonoid zones can be separated, from the Dzhulfites zalensis zone to the Arasella minuta zone, of which all index ammonoids were recorded from Aras Valley. These zones show a succession of the genera Dzhulfites, Paratirolites, Alibashites, Abichites, and Arasella, which occur with some overlap. The diversity dynamics, size decrease, and morphological simplification were illustrated and discussed by Kiessling et al. (2018).

Neither ammonites nor nautiloids were recorded from the post-extinction Aras Member; only rare and poorly preserved small ammonoids occur in the basal Claraia Beds. We interpreted this disappearance of cephalopods at the extinction horizon as true extinctions of the taxa. A decrease in the preservation potential for calcitic fossils from the Paratirolites Limestone to the Aras Member, which may also mimic an extinction, is rather unlikely in this case. Ammonoids occur, for instance, in a similar lithofacies in the Zal member as impressions in shale or 3-D specimens in marly nodules. 


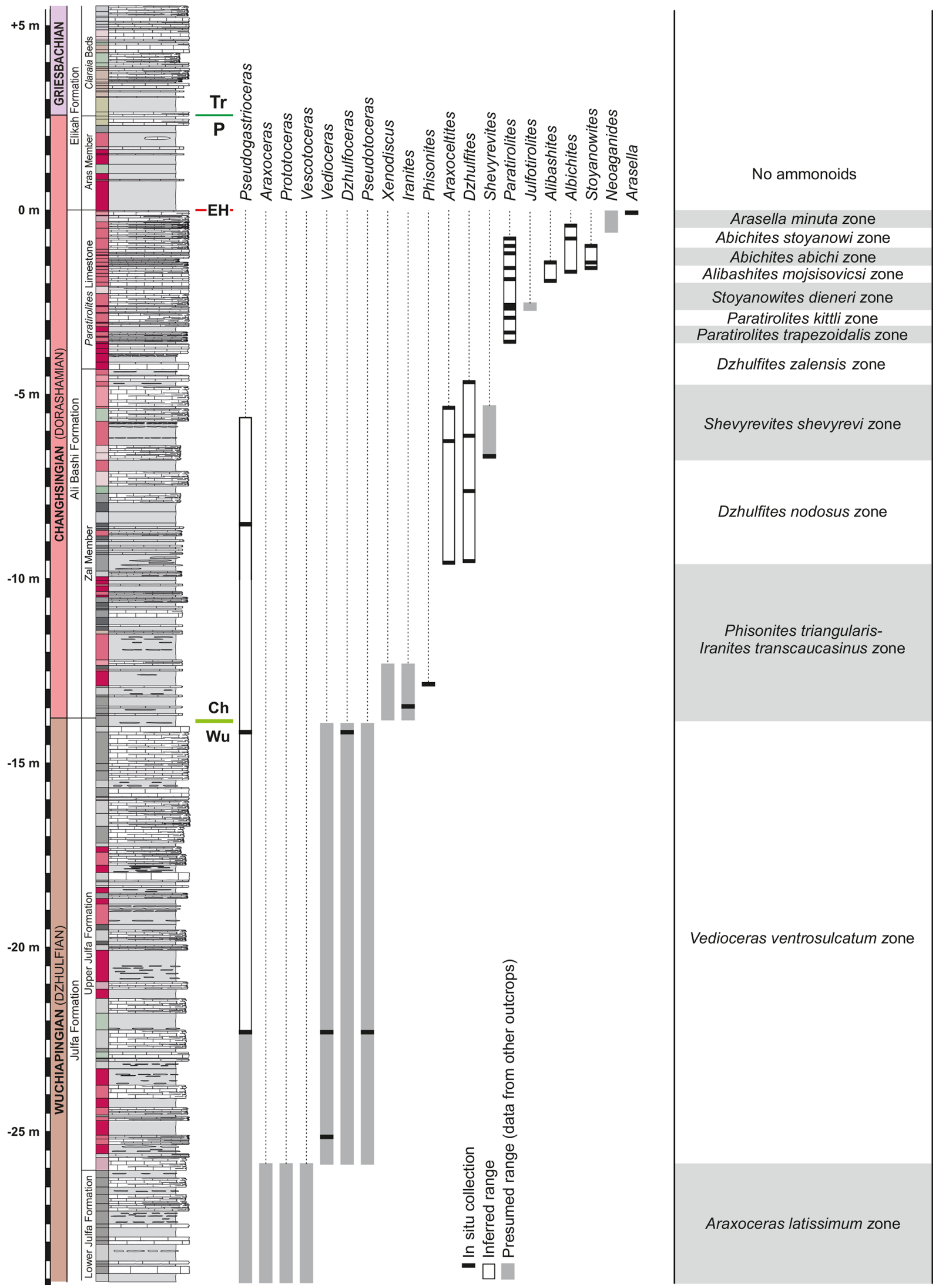

Figure 16. Succession of ammonoid genera in the Aras Valley section. 


\section{Nautiloid succession}

It was shown in previous articles that the late Permian nautiloid assemblages from Dorasham (Shimansky, 1965) and Ali Bashi (Teichert and Kummel, 1973) are remarkable for their high diversity when compared with other Permian occurrences. Already Shimansky (1965) showed that particularly the lower Julfa Formation contains diverse nautiloids with the main nautiloid groups represented.

A total of 62 coiled nautiloid specimens are available from the Aras Valley section, of which some are figured here (Fig. 17). There is a steep decrease in the frequency of specimens within the section: 53 come from the lower Julfa Formation, six from the upper Julfa Formation, two from the Zal Member, and only one from the Paratirolites Limestone. Parallel to the frequency of nautiloid specimens, there is a decrease in genus and species richness within the section (Table 1). In the lower Julfa Formation occur at least six genera and 15 species of coiled nautiloids, and each of the four major late Permian nautiloid superfamilies is represented: Tainoceratoidea (Metacoceras, Pleuronautilus), Trigonoceratoidea (Endolobus), Aipoceratoidea (Domatoceras), and Liroceratoidea (Liroceras, Permonautilus). These taxa cover almost the entire morphological spectrum of late Permian nautiloid conch geometry, from thinly discoidal to globular and from widely umbilicate to involute (Korn et al., 2019b). It is evident that this early Wuchiapingian nautiloid assemblage differs, in its generic composition, from the other two major regions with time-equivalent nautiloid assemblages, the Salt Range (Waagen, 1879; Reed, 1931, 1944), and south China (Zhao et al., 1978).

The six nautiloid specimens from the upper Julfa Formation belong to five genera and only two superfamilies are present: Tainoceratoidea (Tainoceras) and the dominant Liroceratoidea (Liroceras, Permonautilus, Peripetoceras, Coelogasteroceras). It is interesting that this assemblage resembles, in the morphological spectrum, the Changhsingian nautiloid assemblage from the Bellerophon Formation of the Dolomites (Prinoth and Posenato, 2007).

The impoverished nautiloid assemblages from the $\mathrm{Zal}$ Member (with only the two tainoceratoid genera Pleuronautilus and Tirolonautilus) and Paratirolites Limestone (with only one single poorly preserved specimen of Paranautilus) show that the nautiloid-dominated cephalopod communities of the lower Julfa Formation have been replaced by ammonoid-dominated cephalopod communities towards the end of the Permian sedimentary succession.

\section{Carbon isotopes}

A total of 127 carbonate samples from -19.95 to $+5.40 \mathrm{~m}$, spanning from the upper part of the Julfa Formation, to the Ali Bashi Formation including the Paratirolites Limestone, the Aras Member, and the lower part of the Claraia Beds, were taken for the study of $\delta^{13} \mathrm{C}_{\text {carb }}$ (Fig. 18, Table S3). The carbon isotopic ratios were measured from resulting $\mathrm{CO}_{2}$ using an isotope-ratio mass spectrometer (IRMS) of the type Thermo-Finnigan Delta V Advantage coupled with a GasBench II at the Museum für Naturkunde Berlin (Schobben et al., 2017). The used standard "shattercone" reference material was created by the Museum für Naturkunde Berlin by calibrating the homogenized carbonate against Vienna Pee Dee Belemnite (VPDB) using the IAEA reference materials NBS-18 and NBS-19. The resulting isotope ratios are expressed in the conventional delta notation $\left(\delta^{18} \mathrm{O}\right.$ and $\left.\delta^{13} \mathrm{C}\right)$ in relation to VPDB.

Following stable $\delta^{13} \mathrm{C}_{\text {carb }}$ values of around $+4 \%$ in the Wuchiapingian to early Changhsingian part of the section, a first-order $\delta^{13} \mathrm{C}_{\text {carb }}$ trend to $4 \%$ - $5 \%$ o lower values starts at the base of the $C$. yini zone above the marker bed at $-2.20 \mathrm{~m}$ (AV190; peloidal-foraminiferal packstone). It reaches a value of $+1.2 \%$ immediately below the extinction horizon in the uppermost centimetres of the Paratirolites Limestone. The negative trend continues throughout the Aras Member; it reaches the zenith with the most negative $\delta^{13} \mathrm{C}_{\text {carb }}$ value $(-0.7 \%$ o $)$ in the lowermost sample of the Hindeodus parvus zone at the base of the Claraia Beds.

The carbon isotope composition of bulk micritic rock has become an important correlative tool for the PTB strata (Scholle and Arthur, 1980; Jenkyns and Clayton, 1986; Baud et al., 1989; Korte and Kozur, 2010). Global correlative schemes based on these chemostratigraphic records hinge on the observation that the isotope signal traces the ancient oceanic dissolved carbonate (DIC)-carbon isotope composition (Kump, 1991; Dickens et al., 1995). Due to the long residence time of DIC in the marine reservoir and changes in the cycling of carbon between the Earth's surface reservoirs, the so-called biogeochemical carbon cycle should result in $\mathrm{C}$ isotopic excursions of the same sign across the world's oceans (but see Swart, 2008, for a different view). These trends in DIC carbon isotope composition can then be recorded in carbonate minerals that are precipitated in close equilibrium to seawater (such as shells, tests) (Marshall, 1992). This primary observation underlies the assertion that broad-scale stratigraphic trends to both negative and positive $\delta^{13} \mathrm{C}_{\text {carb }}$ excursions can be correlated between sedimentary sequences around the globe. For instance, Early Triassic carbon isotope trends recorded in the $\mathrm{Zal}$ section have been correlated globally (Clarkson et al., 2013; Grasby et al., 2013). However, the degree to which stratigraphically relevant information is captured in $\delta^{13} \mathrm{C}_{\text {carb }}$ records can vary and depends on many factors, such as carbonate mineralogy changes (Brand et al., 2012), diagenetic resetting (Marshall, 1992; Schobben et al., 2016), sedimentary continuity in conjunction with the sampling resolution, and bioturbation intensity (Schobben et al., 2017). As such, we refrained from an overly detailed description of the here-produced $\delta^{13} \mathrm{C}_{\text {carb }}$ record, and we only describe first-order trends over broad stratigraphic intervals (Schobben et al., 2019). 

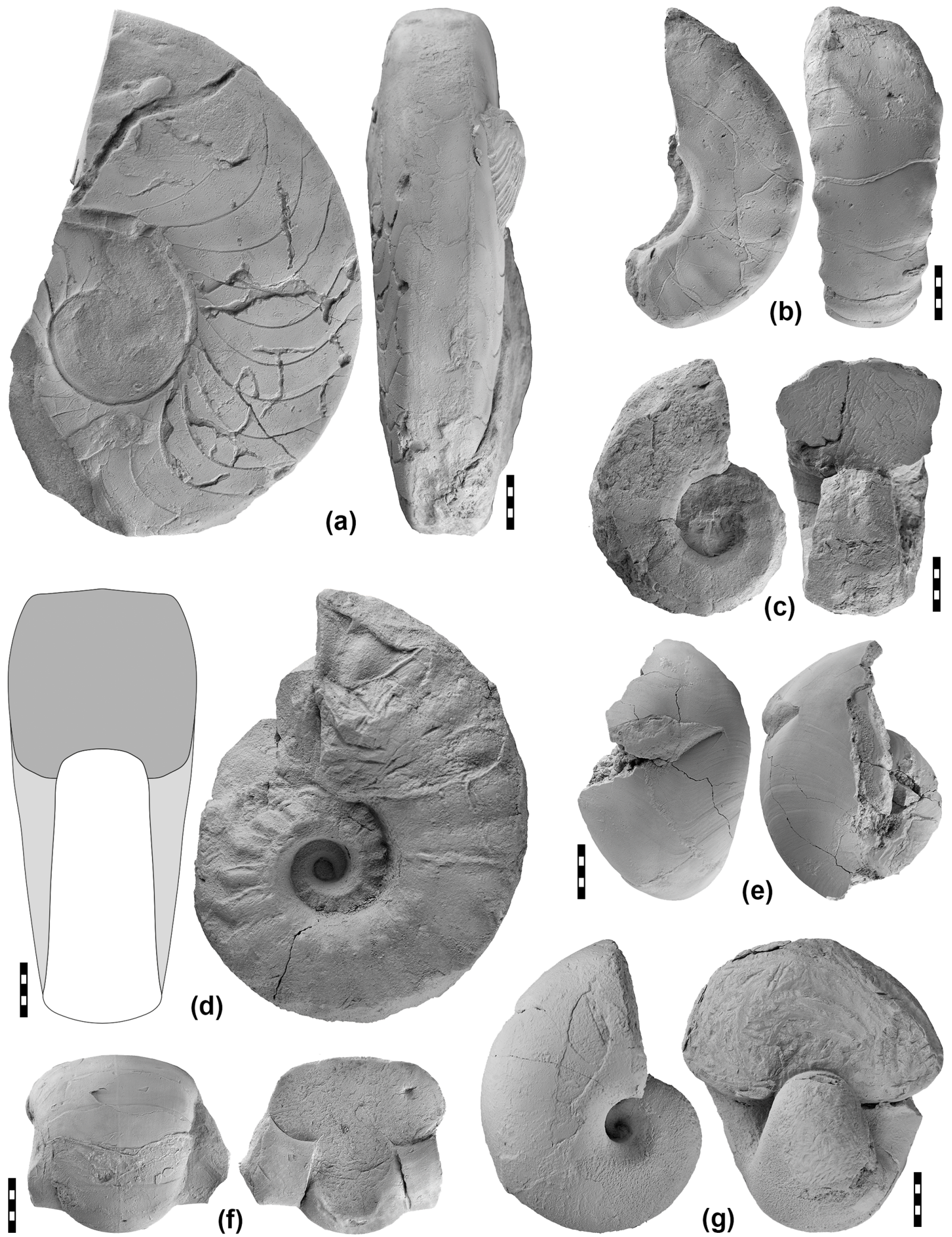

Figure 17. Selected representatives of nautiloids from the Aras Valley section. (a) Domatoceras parallelum (Abich, 1878), specimen MB.C.29346 from the lower Julfa Formation. (b) Pleuronautilus sp., specimen MB.C.29347 from the lower Julfa Formation. (c) Tainoceras (?) sp., specimen MB.C.29348 from the upper Julfa Formation. (d) Pleuronautilus sp., specimen MB.C.29349 from the Zal Member. (e) Liroceras sp., specimen MB.C.29350 from the lower Julfa Formation. (f) Permoceras abichi (Kruglov, 1928), specimen MB.C.29351 from the lower Julfa Formation. (g) Liroceras sp., specimen MB.C.29352 from the lower Julfa Formation. 


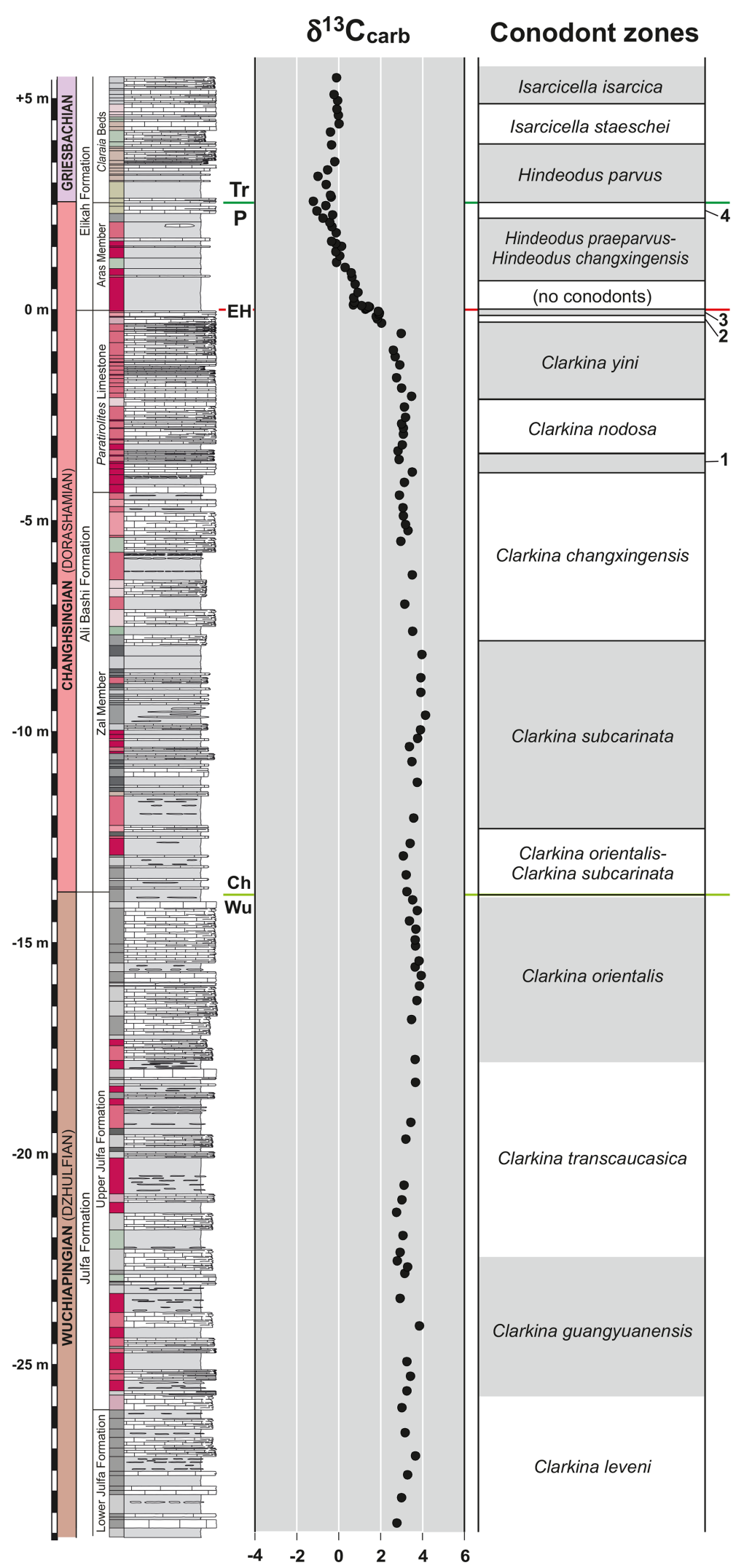

Figure 18. Succession carbon isotopes $\left(\delta^{13} \mathrm{C}_{\text {carb }}\right)$ in the Aras Valley section and correlation with the conodont stratigraphy. Abbreviated conodont zones: (1) Clarkina bachmanni, (2) Clarkina abadehensis, (3) Clarkina hauschkei, (4) Merrillina ultima-Stepanovites mostleri. 
Table 1. Species of coiled nautiloids per genus in the four late Permian rock members of the Aras Valley section.

\begin{tabular}{|c|c|c|c|c|}
\hline Genus & Lower Julfa beds & Upper Julfa beds & Zal Member & Paratirolites Limestone \\
\hline Domatoceras & Five & & & \\
\hline Endolobus & Three & & & \\
\hline Liroceras & Two & One & & \\
\hline Metacoceras & Two & & & \\
\hline Permonautilus & One & One & & \\
\hline Pleuronautilus & Two & & One & \\
\hline Coelogasteroceras & & One & & \\
\hline Peripetoceras & & One & & \\
\hline Tainoceras & & One & & \\
\hline Tirolonautilus & & & One & \\
\hline Paranautilus & & & & One \\
\hline
\end{tabular}

The first-order stratigraphic pattern in the Aras Valley sequence is compatible with $\delta^{13} \mathrm{C}$ records from various regions (e.g. Dolomites, Búkkk Mountains, Oman, central and NW Iran, Tibet, and Kashmir) (Korte and Kozur, 2010; Schobben et al., 2017), as well as organic carbon trends in western and Arctic Canada and Spitsbergen (Grasby and Beauchamp, 2009; Grasby et al., 2013, 2015; Wang et al., 1994). The lowest $\delta^{13} \mathrm{C}$ values were documented near the PTB in the Aras Valley section in the uppermost sample of the Aras Member in the M. ultima-S. mostleri Assemblage zone. This zone can be correlated with the upper part of the $H$. changxingensisC. zhejiangensis zone at Meishan, which shows a similar $\delta^{13} \mathrm{C}_{\text {carb }}$ excursion (Yuan et al., 2014).

This trend occurs over an estimated time span of 0.5 to $1 \mathrm{Myr}$ when considering the independent biostratigraphic information gained in our work and updated age models (e.g. Burgess et al., 2014, 2017; Black et al., 2018). Several scenarios have been put forward over the last decades that tried to identify the external force behind this chemostratigraphic marker. Most scenarios indicate a global-scale carbon cycle perturbation that simultaneously relates to the dramatic ecological and biological disaster unfolding at this system boundary (e.g. Berner, 2002; Xie et al., 2007; Rothman et al., 2014), although some view the $\delta^{13} \mathrm{C}_{\text {carb }}$ excursion as a result of the extinction (Rampino and Caldeira, 2005). A sudden ocean overturn of a previously stagnant ocean resulting in the upwelling of ${ }^{13} \mathrm{C}$-depleted DIC and erosion of organic-rich sediments stored on the continental shelf forced by a global sea-level drop have been implicated in the formation of limestone with a low $\delta^{13} \mathrm{C}$ value (Knoll et al., 1996; Berner, 2002). Another frequently proposed scenario is the catastrophic destabilization of methane clathrates, injecting ${ }^{13} \mathrm{C}$-depleted carbon in the exogenic carbon reservoirs (Benton and Twitchett, 2003). However, in view of recent radiometric dating developments, these scenarios are generally assumed to have acted on short timescales $(<100 \mathrm{kyr})$; they are incompatible with the long duration of the negative inflection of the PTB $\delta^{13} \mathrm{C}$ record (e.g. Burgess et al., 2014, 2017; Majorowicz et al., 2014; Black et al., 2018). In addition, a sud- den ocean overturn is incompatible with currently favoured scenarios involving a well-ventilated ocean superseded by an anoxic and more sluggish ocean circulation (Hotinski et al., 2001; Winguth and Winguth, 2011), and, although a shortterm regression does mark the PTB beds, a long-term major transgression follows this more subtle sea-level drop (Hallam and Wignall, 1999; Grasby and Beauchamp, 2009). It thus follows that these scenarios are likely only of moderate applicability for driving the negative $\delta^{13} \mathrm{C}$ trend. Moreover, the resistance of the DIC pool to a short-term $\mathrm{C}$ injection by methane clathrate dissociation might have been much larger due to the much larger size of this marine chemical reservoir comparative to the modern ocean (Ridgwell, 2005). In spite of this, sub-100 kyr carbon isotope excursions (CIEs) superimposed on the first-order trend, as recognized by some authors, might be compatible with previously cited scenarios. The global importance of sub-100 kyr CIEs has yet to be proven, and we therefore refrain from using them for correlative purposes in this study.

On a more positive note, updated age models can also help to better deconvolve the nature and drivers of the negative inflections in the PTB $\delta^{13} \mathrm{C}$ record (e.g. Burgess et al., 2014, 2017; Baresel et al., 2017; Black et al., 2018). Grasby et al. (2013) showed that both negative and positive CIEs through the late Permian to Early Triassic are consistent in both carbonate carbon and organic carbon records; this rules out something like changes in rates of marine organic carbon burial and supports changes to the external $\mathrm{C}$ pool as the driver for the CIEs.

The state-of-the-art radiometric ages do provide robust support for coeval massive magmatic activity associated with the large igneous province (known as the Siberian Traps basalts) and the first-order negative CIE (e.g. Burgess et al., 2014). More specifically, the lowest $\delta^{13} \mathrm{C}$ values seem to coincide with an episode of extensive intrusive basalt emplacement of this LIP (Burgess et al., 2017). This intrusive phase of Siberian Traps basalts would encompass sill emplacement in the sedimentary basins beneath the flood basalts. Such intrusions baked the rock units in which the magma penetrated, 
which included both evaporites and organic-rich strata, causing the release of large amounts of halocarbons and ${ }^{13} \mathrm{C}$ depleted carbon gas. Supporting evidence comes from abundant breccia pipes in Siberia, which formed as a result of explosive, gas-release events (Svensen et al., 2009; Burgess et al., 2017). Besides being the harbinger of environmental destruction, venting of greenhouse gas would have introduced ${ }^{13} \mathrm{C}$-depleted carbon in the exogenic carbon reservoirs. This observation is important as it is normally assumed that volcanogenic carbon dioxide has a $\delta^{13} \mathrm{C}$ value of $-5 \%$, which is only moderately lighter than the value in the oceans and atmosphere to which it is being added. Thermogenic gas release with $\delta^{13} \mathrm{C}$ values that could have approached as much as $-25 \%$, or even lower $(\sim-50 \%$ o) when concerning methane gas, therefore has a higher potential to have caused the negative carbon isotope excursion as recorded in limestone, without having to invoke unrealistically high carbonrelease scenarios (Berner, 2002). Identifying the cause for observed carbon isotope fluctuations remains challenging, an effect, above all, related to limitations of the isotope recording potential of bulk carbonate rock and uncertainties in flux estimates. The release of greenhouse gas by intrusive volcanism provides, however, a promising prospect in the search for a common driver of the negative $\mathrm{C}$ isotope inflection and the causes behind this mass extinction event. In addition, this volcanically induced carbon gas release might have generated a geochemical anomaly that can serve as a first-order feature in a chemostratigraphic scheme to correlate PTB beds from across the globe (Korte and Kozur, 2010; Schobben et al., 2019). Hence, the negative carbonate-carbon isotope excursion as recorded in the Aras Valley succession is supportive of a relatively complete sequence of the PTB interval.

\section{Conclusions}

The multidisciplinary investigation of the Aras Valley section shows that this complete sedimentary succession spanning the Permian-Triassic boundary has great potential for studying the change of environmental conditions that paralleled the end-Permian mass extinction. The lithological succession; carbonate microfacies characteristics; stable isotope dynamics; and conodont, ostracod, and ammonoid stratigraphy allow for a detailed study of the chronological succession of events and correlation with other PTB sections. In summary, the investigation of the fossil inventory and the geochemical patterns contains the following information.

1. The lithological succession allows the clear separation of three formations (Julfa, Ali Bashi, and Elikah formations), all of which can be subdivided in two members.

2. The end-Permian extinction horizon is marked by the occurrence of a sponge packstone in the uppermost Paratirolites Limestone, which is followed by the shaledominated Aras Member (Boundary Clay).
3. The carbonate microfacies analysis indicates an open marine setting with a general deepening trend from the Julfa Formation (Wuchiapingian), continuing through the Zal Member and the Paratirolites Limestone (endChanghsingian). Small-scale changes appear to indicate shallower settings, which are indicated in two horizons in the upper Julfa Formation and the Paratirolites Limestone. The extinction horizon in the uppermost part of the Paratirolites Limestone is marked by the occurrence of a sponge packstone, consisting of keratose demosponges (sensu Luo and Reitner, 2014). This characteristic sponge spike is a typical marker bed for the end-Permian mass extinction in all sections between the Aras Valley and Ali Bashi (Leda et al., 2014). The subsequent transition to the Aras Member does not show significant bathymetric changes. However, cessation of the carbonate production caused a lithological change to shale-dominated deposits. Calcitic fan-like structures, typical sediment structures of post-extinction deposits, suggest an unusual seawater chemistry with possibly increased total alkalinity. Possible microbial structures were identified in the Claraia Beds, which may represent a formation equivalent to Early Triassic microbialites of other Tethyan sections. The facies analysis does not reveal any indications about a bathymetric change within the Claraia Beds; however, nearby sections (Ali Bashi and Zal) indicate a temporally shallower environment (Leda et al., 2014).

4. The fossil content of the Aras Valley section is exceptionally high compared to time-equivalent sections in the Transcaucasian-NW Iranian region.

a. The conodonts show a complete succession with four Wuchiapingian, 10 Changhsingian, and three Griesbachian zones; all carbonate beds yielded productive samples. The Permian-Triassic boundary can precisely be determined at $2.55 \mathrm{~m}$ above the extinction horizon.

b. The ostracod analysis reveals a local extinction and complete faunal turnover, immediately at the base of the Aras Member (Boundary Clay). The speciespoor Fabalicypris-dominated pre-extinction assemblage changes to a diverse Bairdiacypris-dominated post-extinction assemblage in the Aras Member. The middle part of the Aras Member is marked by mass occurrences mainly of Bairdiacypris ottomanensis, which may be regarded as a disaster taxon, appearing in several Tethyan sections at the end-Permian mass extinction event. The high abundance of Bairdiidae in the whole succession suggests an open marine environment with normal marine salinity and oxygen concentrations.

c. The nautiloid and ammonoid successions indicate a change from a shallow-water nautiloid-dominated 
cephalopod community in the lower Julfa Formation to a deep-water ammonoid-dominated cephalopod community towards the extinction horizon. Neither of the groups were recorded from the post-extinction Aras Member; only rare and poorly preserved small ammonoids occur in the basal Claraia Beds.

5. The carbon isotope results document a negative $\delta^{13} \mathrm{C}_{\mathrm{carb}}$ trend starting $2 \mathrm{~m}$ below the extinction horizon, above the marker bed of the peloidal-foraminiferal packstone. The $\delta^{13} \mathrm{C}_{\mathrm{carb}}$ values range from $4 \%$ in the Wuchiapingian and early Changhsingian to $-0.7 \%$ in the lowermost sample of the Hindeodus parvus zone. This firstorder $\delta^{13} \mathrm{C}$ signal can serve as a chemostratigraphic marker for the correlation with other PTB successions.

Data availability. Data $\left(\mathrm{CaCO}_{3}\right.$ content, $\delta^{13} \mathrm{C}$ values $)$ related to this article are available in the Supplement.

Supplement. The supplement related to this article is available online at: https://doi.org/10.5194/fr-23-33-2020-supplement.

Author contributions. JG, NG, AG, LL, MS, and DK collected the investigated material in the field. US performed the lab analysis of stable isotopes. The various aspects were studied by AG, DK, and LL (lithological succession); LL and ST (facies); MS and US (stable isotopes); AG (conodonts); JG and MBF (ostracods); DK and AG (ammonoids); and DK and NGT (nautiloids). All authors contributed to the concept of the study and writing of the manuscript.

Competing interests. The authors declare that they have no conflict of interest.

Acknowledgements. We are indebted to the Aras Free Zone Office (Julfa) for the support of the field sessions. We thank Kathleen Schindler (Berlin) for processing the ostracod samples, Markus Brinkmann (Berlin) for preparation of the cephalopod specimens, and Jenny Huang and Jamie Lembke (Berlin) for taking photographs of the cephalopods. We also acknowledge the reviews of an earlier version by Lara Locatelli and Marc Leu (Zürich), Sylvain Richoz (Lund), and an anonymous reviewer. The project was supported by the Deutsche Forschungsgemeinschaft (DFG projects Ko1829/12-1, Ko1829/18-1 as well as the TERSANE research group FOR 2332). NGT was funded by the Ferdowsi University of Mashhad, Iran.

Financial support. This research has been supported by the Deutsche Forschungsgemeinschaft (grant nos. Ko1829/12-1, Ko1829/18-1, and FOR 2332).
Review statement. This paper was edited by Christian Klug and reviewed by Marc Leu, Lara Locatelli, and one anonymous referee.

\section{References}

Abich, H.: Geologische Forschungen in den kaukasischen Ländern, Theil I. Eine Bergkalkfauna aus der Araxesenge bei Djoulfa in Armenien, Hölder, Wien, 1-128 pp., 1878.

Altiner, D., Baud, A., Guex, J., and Stampfli, G.: La limite PermienTrias dans quelques localités du Moyen-Orient: Recherches stratigraphiques et micropaléontologique, Rivista Italiana di Paleontologia e Stratigrafia, 85, 683-714, 1980.

Arakelyan, R. A., Grunt, T. A., and Shevyrev, A. A.: Kratkiy stratigraficheskiy ocherk, in: Rasvitie i smena morskikh organizmov na rubezhe Paleozoya i Mezozoya, edited by: Ruzhencev, V. E. and Sarytcheva, T. G., Trudy Paleontologicheskogo Instituta Akademiya Nauk SSSR, 108, 20-25, 1965.

BadriKolalo, N., Hamdi, B., Vaziri, S. H., and Aghanabati, S. A.: Biostratigraphic Correlation of Elikah Formation in Zal Section (Northwestern Iran) with Ruteh and Type Sections in Alborz Mountains Based on Conodonts, Iranian Journal of Earth Sciences, 7, 78-88, 2015.

Bagherpour, B., Bucher, H., Baud, A., Brosse, M., Vennemann, T., Martini, R., and Guodun, K.: Onset, development, and cessation of basal Early Triassic microbialites (BETM) in the Nanpanjiang pull-apart Basin, South China Block, Gondwana Res., 44, 178204, 2017.

Baresel, B., Bucher, H., Brosse, M., Cordey, F., Guodun, K., and Schaltegger, U.: Precise age for the Permian-Triassic boundary in South China from high-precision U-Pb geochronology and Bayesian age-depth modeling, Solid Earth, 8, 361-378, https://doi.org/10.5194/se-8-361-2017, 2017.

Baud, A., Magaritz, M., and Holser, W. T.: Permian-Triassic of the Tethys: Carbon isotope studies, Geol. Rundsch., 78, 649-677, 1989.

Baud, A., Cirilli, S., and Marcoux, J.: Biotic response to mass extinction: the lowermost Triassic microbialites, Facies, 36, 238242, 1997.

Baud, A., Atudorei, V., and Richoz, S.: Sea-floor carbonate fans and calcimicrobial mound in the lower Triassic red limestone of the Alwa Formation, Baid Exotic, Eastern Oman Mountains, 24th IAS meeting of Sedimentology, 2005a.

Baud, A., Richoz, S., and Marcoux, J.: Calcimicrobial cap rocks from the basal Triassic units: western Taurus occurrences (SW Turkey), Comptes Rendus Palevol, 4, 569-582, 2005 b.

Belousova, Z. D.: Podklass Ostracoda, in: Rasvitie i smena morskikh organizmov na rubezhe Paleozoya i Mezozoya, edited by: Ruzhencev, V. E. and Sarytcheva, T. G., Trudy Paleontologicheskogo Instituta Akademiya Nauk SSSR, 108, 254-265, 1965.

Benton, M. J. and Twitchett, R. J.: How to kill (almost) all life: the end-Permian extinction event, Trends Ecol. Evol., 18, 358-365, 2003.

Berner, R. A.: Examination of hypotheses for the Permo-Triassic boundary extinction by carbon cycle modeling, P. Natl. Acad. Sci. USA, 99, 4172-4177, 2002.

Black, B. A., Neely, R. R., Lamarque, J.-F., Elkins-Tanton, L. T., Kiehl, J. T., Shields, C. A., Mills, M. J., and Bardeen, C.: Sys- 
temic swings in end-Permian climate from Siberian Traps carbon and sulfur outgassing, Nat. Geosci., 11, 949-954, 2018.

Brand, U., Posenato, R., Came, R., Affek, H., Angiolini, L., Azmy, K., and Farabegoli, E.: The end-Permian mass extinction: A rapid volcanic $\mathrm{CO}_{2}$ and $\mathrm{CH}_{4}$-climatic catastrophe, Chem. Geol., 322, 121-144, 2012.

Burgess, S. D., Bowring, S., and Shen, S.: High-precision timeline for Earth's most severe extinction, P. Natl. Acad. Sci. USA, 111, 3316-3321, 2014.

Burgess, S. D., Muirhead, J. D., and Bowring, S. A.: Initial pulse of Siberian Traps sills as the trigger of the end-Permian mass extinction, Nat. Comm., 8, 1-6, 2017.

Chen, T.: Permian ostracods from the Chihsia limestone of Lungtan, Nanking, Acta Palaeontol. Sin., 6, 215-257, 1958.

Chen, Z., Tong, J., Liao, Z., and Chen, J.: Structural changes of marine communities over the Permian-Triassic transition: ecologically assessing the end-Permian mass extinction and its aftermath, Glob. Planet. Change, 73, 123-140, 2010.

Clarkson, M., Richoz, S., Wood, R., Maurer, F., Krystyn, L., McGurty, D., and Astratti, D.: A new high-resolution $\delta^{13} \mathrm{C}$ record for the Early Triassic: insights from the Arabian Platform, Gondwana Res., 24, 233-242, 2013.

Collinson, J. W., Kendall, C. G. S. C., and Marcantel, J. B.: Permian-Triassic boundary in eastern Nevada and west-central Utah, Geol. Soc. Am. Bull., 87, 821-824, 1976.

Crasquin-Soleau, S., Broutin, J., Roger, J., Platel, J.-P., Al Hashmi, H., Angiolini, L., Baud, A., Bucher, H., and Marcoux, J.: First Permian ostracode fauna from the Arabian Plate (Khuff Formation, Sultanate of Oman), Micropaleontology, 45, 163-182, 1999.

Crasquin-Soleau, S., Marcoux, J., Angiolini, L., and Nicora, A.: Palaeocopida (Ostracoda) across the Permian-Triassic events: new data from southwestern Taurus (Turkey), J. Micropalaeontol., 23, 67-76, https://doi.org/10.1144/jm.23.1.67, 2004a.

Crasquin-Soleau, S., Marcoux, J., Angiolini, L., Richoz, S., Nicora, A., Baud, A., and Bertho, Y.: A new ostracode fauna from the Permian-Triassic boundary in Turkey (Taurus, Antalya Nappes), Micropaleontology, 50, 281-295, 2004b.

Crasquin-Soleau, S., Vaslet, D., and Le Nindre, Y. M.: Ostracods as markers of the Permian/Triassic boundary in the Khuff Formation of Saudi Arabia, Palaeontology, 48, 853-868, 2005.

Crasquin-Soleau, S., Carcione, L., and Martini, R.: Permian ostracods from the Lercara Formation (Middle Triassic-Carnian), Sicily, Italy, Palaeontology, 51, 537-560, 2008.

Dickens, G. R., O’Neil, J. R., Rea, D. K., and Owen, R. M.: Dissociation of oceanic methane hydrate as a cause of the carbon isotope excursion at the end of the Paleocene, Paleoceanography, 10, 965-971, 1995.

Dunham, R. J.: Classification of carbonate rocks according to depositional textures, Memoires of the American Association of Petroleum Geologists, 1, 108-121, 1962.

Embry, A. F. and Klovan, J. E.: Absolute water depth limits of Late Devonian paleoecological zones, Geol. Rundsch., 61, 672-686, 1972.

Erwin, D. H.: The Permo-Triassic extinction, Nature, 367, 231-236, 1994.

Erwin, D. H., Bowring, S. A., and Yugan, J.: End-Permian mass extinctions: a review, Special Papers, Geol. Soc. Am., 356, 363384, 2002.
Farabegoli, E. and Perri, M. C.: Millennial Physical Events and the End-Permian Mass Mortality in the Western Palaeotethys: Timing and Primary Causes, in: Earth and Life, edited by: Talent, J. A., International Year of Planet Earth. Springer, Dordrecht, 719758, 2012.

Flügel, E.: Microfacies of carbonate rocks, Springer, Berlin, 976 pp., 2004.

Forel, M.-B.: Ostracods (Crustacea) associated with microbialites across the Permian-Triassic boundary in Dajiang (Guizhou Province, south China), Eur. J. Taxon., 19, 1-34, 2012.

Forel, M.-B.: Heterochronic growth of ostracods (Crustacea) from microbial deposits in the aftermath of the end-Permian extinction, J. Syst. Palaeontol., 13, 315-349, 2014.

Forel, M.-B., Crasquin, S., Kershaw, S., Feng, Q., and Collin, P.Y.: Ostracods (Crustacea) and water oxygenation in the earliest Triassic of South China: implications for oceanic events at the end-Permian mass extinction, Aust. J. Earth Sci., 56, 815-823, 2009.

Forel, M.-B., Crasquin, S., Chitnarin, A., Angiolini, L., and Gaetani, M.: Precocious sexual dimorphism and the Lilliput effect in Neo-Tethyan Ostracoda (Crustacea) through the PermianTriassic boundary, Palaeontology, 58, 409-454, 2015.

Foster, W. J., Danise, S., Price, G. D., and Twitchett, R. J.: Subsequent biotic crises delayed marine recovery following the late Permian mass extinction event in northern Italy, PloS One, 12, e0172321, https://doi.org/10.1371/journal.pone.0172321, 2017.

Foster, W. J., Lehrmann, D. J., Yu, M., Ji, L., and Martindale, R. C.: Persistent environmental stress delayed the recovery of marine communities in the aftermath of the latest Permian mass extinction, Paleoceanogr. Paleocl., 33, 338-353, 2018.

Foster, W. J., Heindel, K., Richoz, S., Gliwa, J., Lehrmann, D. J., Baud, A., Kolar-Jurkovšek, T., Aljinović, D., Jurkovšek, B., Korn, D., Martindale, R. C., and Peckmann, J.: Suppressed competitive exclusion enabled the proliferation of Permian/Triassic boundary microbialites, The Depositional Record, 6, 62-74, https://doi.org/10.1002/dep2.97, 2020.

Foster, W. J., Lehrmann, D. J., Yu, M., and Martindale, R. C.: Facies selectivity of benthic invertebrates in a Permian/Triassic boundary microbialite succession: Implications for the "microbialite refuge" hypothesis, Geobiology, 17, 523-535, 2019.

Frech, F.: Geologische Reisebeobachtungen, Beiträge zur Paläontologie Österreich-Ungarns und des Orients, 12, 169-182, 1900a.

Frech, V.: Von Eriwan nach Djulfa, Beiträge zur Paläontologie Österreich-Ungarns und des Orients, 12, 163-168, 1900b.

Friesenbichler, E., Richoz, S., Baud, A., Krystyn, L., Sahakyan, L., Vardanyan, S., Peckmann, J., Reitner, J., and Heindel, K.: Sponge-microbial build-ups from the lowermost Triassic Chanakhchi section in southern Armenia: Microfacies and stable carbon isotopes, Palaeogeogr. Palaeocl., 490, 653-672, 2018.

Ghaderi, A.: Stratigraphy and paleoecology of the Upper Permian to Permian-Triassic boundary in the northwest of Iran based on biostratigraphic data of conodonts and brachiopods, Ph.D., Ferdowsi University of Mashhad, Mashhad, 488 pp., 2014.

Ghaderi, A., Garbelli, C., Angiolini, L., Ashouri, A. R., Korn, D., Rettori, R., and Gharaie, M. H. M.: Faunal change near the endPermian extinction: the brachiopods of the Ali Bashi Mountains, NW Iran, Rivista Italiana di Paleontologia e Stratigrafia, 120, 27 59, 2014a. 
Ghaderi, A., Leda, L., Schobben, M., Korn, D., and Ashouri, A. R.: High-resolution stratigraphy of the Changhsingian (Late Permian) successions of NW Iran and the Transcaucasus based on lithological features, conodonts and ammonoids, Foss. Rec., 17, 41-57, https://doi.org/10.5194/fr-17-41-2014, 2014b.

Ghaderi, A., Sadeghi, A., Ashouri, A. R., and Korn, D.: Study of Late Permian (Wuchiapingian) brachiopods of sedimentary succession at the Zal section, Northwest Iran, Paleontology, 2, 219229, 2015.

Grasby, S., Beauchamp, B., Embry, A., and Sanei, H.: Recurrent Early Triassic ocean anoxia, Geology, 41, 175-178, 2013.

Grasby, S. E. and Beauchamp, B.: Latest Permian to Early Triassic basin-to-shelf anoxia in the Sverdrup Basin, Arctic Canada, Chem. Geol., 64, 232-246, 2009.

Grasby, S. E., Beauchamp, B., Bond, D. P. G., Wignall, P. B., Talavera, C., Galloway, J. M., Piepjohn, K., Reinhardt, L., and Blomeier, D.: Progressive environmental deterioration in northwestern Pangea leading to the latest Permian extinction, Geol. Soc. Am. Bull., 127, 1331-1347, 2015.

Grunt, T. A.: Nadsemeystvo Athyridacea, in: Rasvitie i smena morskikh organizmov na rubezhe Paleozoya i Mezozoya,,edited by: Ruzhencev, V. E. and Sarytcheva, T. G., Trudy Paleontologicheskogo Instituta Akademiya Nauk SSSR, 108, 237-253, 1965.

Hallam, A. and Wignall, P.: Mass extinctions and sea-level changes, Earth-Sci. Rev., 48, 217-250, 1999.

Heindel, K., Foster, W. J., Richoz, S., Birgel, D., Roden, V. J., Baud, A., Brandner, R., Krystyn, L., Mohtat, T., and Koşun, E.: The formation of microbial-metazoan bioherms and biostromes following the latest Permian mass extinction, Gondwana Res., 61, 187-202, 2018.

Heydari, E., Hassanzadeh, J., Wade, W., and Ghazi, A.: PermianTriassic boundary interval in the Abadeh section of Iran with implications for mass extinction: Part 1 - Sedimentology, Palaeogeogr. Palaeocl., 193, 405-423, 2003.

Heydari, E., Arzani, N., and Hassanzadeh, J.: Mantle plume: The invisible serial killer - Application to the Permian-Triassic boundary mass extinction, Palaeogeogr. Palaeocl., 264, 147-162, 2008.

Hips, K. and Haas, J.: Calcimicrobial stromatolites at the PermianTriassic boundary in a western Tethyan section, Bükk Mountains, Hungary, Sediment. Geol., 185, 239-253, 2006.

Hofmann, R., Hautmann, M., Brayard, A., Nuetzel, A., Bylund, K. G., Jenks, J. F., Vennin, E., Olivier, N., and Bucher, H.: Recovery of benthic marine communities from the end-Permian mass extinction at the low latitudes of eastern Panthalassa, Palaeontology, 57, 547-589, 2014.

Hofmann, R., Buatois, L. A., MacNaughton, R. B., and Mángano, M. G.: Loss of the sedimentary mixed layer as a result of the endPermian extinction, Palaeogeogr. Palaeocl., 428, 1-11, 2015.

Holser, W. and Magaritz, M.: Events near the Permian-Triassic boundary, Modern Geol., 11, 155-180, 1987.

Horacek, M., Brandner, R., and Abart, R.: Carbon isotope record of the P/T boundary and the Lower Triassic in the Southern Alps: evidence for rapid changes in storage of organic carbon, Palaeogeogr. Palaeocl., 252, 347-354, 2007a.

Horacek, M., Richoz, S., Brandner, R., Krystyn, L., and Spötl, C.: Evidence for recurrent changes in Lower Triassic oceanic circulation of the Tethys: The $\delta^{13} \mathrm{C}$ record from marine sections in Iran, Palaeogeogr. Palaeocl., 252, 355-369, $2007 \mathrm{~b}$.
Hotinski, R. M., Bice, K. L., Kump, L. R., Najjar, R. G., and Arthur, M. A.: Ocean stagnation and end-Permian anoxia, Geology, 29, 7-10, 2001.

Isaa, A., Ghaderi, A., Ashouri, A. R., and Korn, D.: Late Permian - Early Triassic conodonts of the Zal section at the northwest of Iran, Stratigraphy and Sedimentology Researches, 32, 55-74, 2016.

Jattiot, R., Bucher, H., Brayard, A., Brosse, M., Jenks, J. F., and Bylund, K. G.: Smithian ammonoid faunas from northeastern Nevada: implications for Early Triassic biostratigraphy and correlation within the western USA basin, Palaeontogr. Abt. A, 309 1-89, 2017.

Jenkyns, H. C. and Clayton, C. J.: Black shales and carbon isotopes in pelagic sediments from the Tethyan Lower Jurassic, Sedimentology, 33, 87-106, 1986.

Jin, Y., Wardlaw, B. R., Glenister, B. F., and Kotlyar, G. V.: Permian chronostratigraphic subdivisions, Episodes, 20, 10-15, 1997.

Jin, Y., Henderson, C. M., Wardlaw, B. R., Glenister, B. F., Mei, S., Shen, S., and Wang, X.: Proposal for the Global Stratotype Section and Point (GSSP) for the Guadalupian-Lopingian boundary, Permophiles, 39, 32-42, 2001.

Kakuwa, Y. and Matsumoto, R.: Cerium negative anomaly just before the Permian and Triassic boundary event - the upward expansion of anoxia in the water column, Palaeogeogr. Palaeocl., 229, 335-344, 2006.

Kershaw, S., Zhang, T., and Lan, G.: A microbialite carbonate crust at the Permian-Triassic boundary in South China, and its palaeoenvironmental significance, Palaeogeogr. Palaeocl., 146, 1-18, 1999.

Kershaw, S., Li, Y., Crasquin-Soleau, S., Feng, Q., Mu, X., Collin, P.-Y., Reynolds, A., and Guo, L.: Earliest Triassic microbialites in the South China block and other areas: controls on their growth and distribution, Facies, 53, 409-425, 2007.

Kershaw, S., Crasquin, S., Li, Y., Collin, P. Y., Forel, M. B., Mu, X., Baud, A., Wang, Y., Xie, S., Maurer, F., and Guo, L.: Microbialites and global environmental change across the Permian-Triassic boundary: a synthesis, Geobiology, 10, 25-47, https://doi.org/10.1111/j.1472-4669.2011.00302.x, 2012.

Kiessling, W., Schobben, M., Ghaderi, A., Hairapetian, V., Leda, L., and Korn, D.: Pre-mass extinction decline of latest Permian ammonoids, Geology, 46, 283-286, 2018.

Knoll, A. H., Bambach, R. K., Canfield, D. E., and Grotzinger, J. P.: Comparative Earth History and Late Permian Mass Extinction, Science, 273, 452-457, 1996.

Knoll, A. H., Fischer, W. W., Gattuso, J., and Hansson, L.: Skeletons and ocean chemistry: the long view, Ocean Acidification, 4, 6782,2011

Kolar-Jurkovšek, T., Jurkovšek, B., Nestell, G. P., and Aljinović, D.: Biostratigraphy and sedimentology of Upper Permian and Lower Triassic strata at Masore, western Slovenia, Palaeogeogr. Palaeocl., 490, 38-54, 2018.

Korn, D. and Ghaderi, A.: The Late Permian araxoceratid ammonoids: a case of repetitive temporal and spatial unfolding of homoplastic conch characters, Neues Jahrb. Geol. P-A, 292, 339-350, 2019.

Korn, D., Ghaderi, A., Leda, L., Schobben, M., and Ashouri, A. R.: The ammonoids from the Late Permian Paratirolites Limestone of Julfa (East Azerbaijan, Iran), J. Syst. Palaeontol., 14, 841-890, 2016. 
Korn, D., Ghaderi, A., and Ghanizadeh Tabrizi, N.: Early Changhsingian (Late Permian) ammonoids from NW Iran, Neues Jahrb. Geol. P-A, 293, 37-56, 2019a.

Korn, D., Ghaderi, A., Ghanizadeh Tabrizi, N., and Gliwa, J.: The morphospace of Late Permian coiled nautiloids, Lethaia, https://doi.org/10.1111/let.12348, 2019b.

Korte, C. and Kozur, H. W.: Carbon isotope stratigraphy across the Permian/Triassic boundary at Jolfa (NW-Iran), Peitlerkofel (Sass de Pütia, Sass de Putia), Pufels (Bula, Bulla), Tesero (all three Southern Alps, Italy) and Gerennavár (Bükk Mts., Hungary), Journal of Alpine Geology, 47, 119-135, 2005.

Korte, C. and Kozur, H. W.: Carbon-isotope stratigraphy across the Permian-Triassic boundary: a review, J. Asian Earth Sci., 39, 215-235, 2010.

Korte, C., Kozur, H. W., and Partoazar, H.: Negative carbon isotope excursion at the Permian/Triassic boundary section at Zal, NW Iran, Hallesches Jahrbuch für Geowissenschaften, Reihe B, Beiheft, 18, 69-71, 2004.

Kotlyar, G. V., Zakharov, Y. D., Koczyrkevicz, B. V., Kropatcheva, G. S., Rostovcev, L. O., Chedija, I. O., Vuks, G. P., and Guseva, E. A.: Posdnepermskiy etap evolyutsii organicheskogo mira. Dzhulficheskiy i dorashamskiy yarusy SSSR, Proekt No 106 ("Permo-Triasovaya stadiya geologicheskoy evolyutsii") Mezhdunarodnoy programmy geologicheskoy korrelyatsii, edited by: Gramm, M. N. and Rostovcev, L. O., NAUKA, Leningrad, 199 pp., 1983.

Kotlyar, G. V., Zakharov, Y. D., Vuks, G. P., Kropatcheva, G. S., Pronina, G. P., Chedija, I. O., and Burago, V. I.: Posdnepermskiy etap evolyutsii organicheskogo mira, Midiskiy yarus SSSR., Proekt No 106 ("Permo-Triasovaya stadiya geologicheskoy evolyutsii") Mezhdunarodnoy programmy geologicheskoy korrelyatsii, edited by: Gramm, M. N. and Rostovcev, L. O., NAUKA, Leningrad, 184 pp., 1989.

Kotlyar, G. V., Kozur, H., and Zakharov, Y. D.: The Transcaucasian sections Dorasham 2 (Azerbaidzhan) and Sovetashen (Armenia), two candidates for P/T boundary reference sections, Albertiana, 12, 36-38, 1993.

Kozur, H., Leven, E. Y., Lozinskiy, V. R., and Pjatakova, M. V.: Division of the Permian-Triassic boundary beds in Trans-Caucasus on the basis of conodonts, Byulleten' Moskovskogo obshchestva ispytatelei prirody, Otdel Geologicheskiy, 53, 15-24, 1978 (in Russian).

Kozur, H., Leven, E. Y., Lozinskiy, V. R., and Pjatakova, M. V.: Subdivision of Permian-Triassic boundary beds in Transcaucasia on the basis of conodonts, Int. Geol. Rev., 22, 361-368, 1980.

Kozur, H. W.: Beiträge zur Conodontenfauna des Perm, Geologisch-Paläontologische Mitteilungen Innsbruck, 5, 1-44, 1975.

Kozur, H. W.: Pelagic uppermost Permian and the Permian-Triassic boundary conodonts of Iran, Part I: Taxonomy, Hallesches Jahrbuch für Geowissenschaften, Reihe B, Beiheft, 18, 39-68, 2004a.

Kozur, H. W.: Pelagic uppermost Permian and the Permian-Triassic boundary conodonts of Iran. Part 1: Taxonomy, Hallesches Jahrbuch für Geowissenschaften, Reihe B, Geologie Paläontologie Mineralogie, 18, 39-68, 2004b.

Kozur, H. W.: Pelagic uppermost Permian and the Permian-Triassic boundary conodonts of Iran. Part II: Investigated sections and evaluation of the conodont faunas, Hallesches Jahrbuch für Geowissenschaften, Reihe B, Beiheft, 19, 49-86, 2005.

Kozur, H. W.: Biostratigraphy and event stratigraphy in Iran around the Permian-Triassic Boundary (PTB): implications for the causes of the PTB biotic crisis, Glob. Planet. Change, 55, 155176, 2007a.

Kozur, H. W.: Biostratigraphy and event stratigraphy in Iran around the Permian-Triassic Boundary (PTB): Implications for the causes of the PTB biotic crisis, Glob. Planet. Change, 55, 155176, 2007b.

Kruglov, M. V.: Verkhne-kamennougol'nye i artinskie nautilidy Urala, Trudy Geologicheskogo Muzeya Akademiya Nauk SSSR, 3, 63-206, 1928.

Kump, L. R.: Interpreting carbon-isotope excursions: Strangelove oceans, Geology, 19, 299-302, 1991.

Leda, L., Korn, D., Ghaderi, A., Hairapetian, V., Struck, U., and Reimold, W. U.: Lithostratigraphy and carbonate microfacies across the Permian-Triassic boundary near Julfa (NW Iran) and in the Baghuk Mountains (Central Iran), Facies, 60, 295-325, 2014.

Lehrmann, D. J., Bentz, J. M., Wood, T., Goers, A., Dhillon, R., Akin, S., Li, X. W., Payne, J. L., Kelley, B. M., Meyer, K. M., Schaal, E. K., Suarez, M. B., Yu, M. Y., Qin, Y. J., Li, R. X., Minzoni, M., and Henderson, C. M.: Environmental controls on the genesis of marine microbialites and dissolution surface associated with the end-Permian mass extinction: new sections and observations from the Nanpanjiang basin, South China, Palaios, 30, 529-552, 2015.

Leonova, T. B.: Permian ammonoid biostratigraphy, in: The Permian Timescale, edited by: Lucas, S. G. and Shen, S. Z., Geological Society, London, Special Publications 455, Geol. Soc. Lond., 19, 185-203, 2016.

Luo, C. and Reitner, J.: First report of fossil "keratose" demosponges in Phanerozoic carbonates: preservation and 3-D reconstruction, Naturwissenschaften, 101, 467-477, 2014.

Majorowicz, J., Grasby, S., Safanda, J., and Beauchamp, B.: Gas hydrate contribution to Late Permian global warming, Earth Planet. Sc. Lett., 393, 243-253, 2014.

Marenco, P. J., Griffin, J. M., Fraiser, M. L., and Clapham, M. E.: Paleoecology and geochemistry of Early Triassic (Spathian) microbial mounds and implications for anoxia following the endPermian mass extinction, Geology, 40, 715-718, 2012.

Marshall, J. D.: Climatic and oceanographic isotopic signals from the carbonate rock record and their preservation, Geol. Mag., 129, 143-160, 1992.

Martindale, R. C., Foster, W., and Velledits, F.: The survival, recovery, and diversification of metazoan reef ecosystems following the end-Permian mass extinction event, Palaeogeogr. Palaeocl., 513, 100-115, https://doi.org/10.1016/j.palaeo.2017.08.014, 2019.

Mei, S., Henderson, C. M., and Cao, C.: Conodont samplepopulation approach to defining the base of the Changhsingian Stage, Lopingian Series, Upper Permian, in: The Palynology and Micropalaeontology of Boundaries, edited by: Beaudoin, A. B. and Head, M. J., 230, Geological Society of London, London, 105-121, 2004.

Mei, S., Jin, Y., and Wardlaw, B. R.: Succession of Wuchiapingian conodonts from northeastern Sichuan and its worldwide correlation, Acta Micropalaeontol. Sin., 11, 121-139, 1994. 
Mei, S., Jin, Y., and Wardlaw, B. R.: Conodont succession of the Guadalupian-Lopingian boundary strata in Laibin of Guangxi, China and West Texas, USA, in: Permian Stratigraphy, Environments and Resources, edited by: Jin, Y., Wardlaw, B. R., and Wang, Y., 9, China University of Science and Technology Press, 53-76, 1998a.

Mei, S., Zhang, K., and Wardlaw, B. R.: A refined succession of Changhsingian and Griesbachian neogondolellid conodonts from the Meishan section, candidate of the global stratotype section and point of the Permian-Triassic boundary, Palaeogeogr. Palaeocl., 143, 213-226, 1998 b.

Melnyk, D. H. and Maddocks, R. F.: Ostracode biostratigraphy of the Permo-Carboniferous of central and north-central Texas, Part I: paleoenvironmental framework, Micropaleontology, 34, 1-20, 1988.

Metcalfe, I.: Changhsingian (Late Permian) conodonts from Son La, northwest Vietnam and their stratigraphic and tectonic implications, J. Asian Earth Sci., 50, 141-149, 2012.

Mette, W.: Upper Permian and lowermost Triassic stratigraphy, facies and ostracods in NW Iran-implications for the P/T extinction event, Stratigraphy, 5, 205-219, 2008.

Mette, W.: Ostracods from the Upper Permian and Permian/Triassic boundary interval of Northwest Iran, Revista española de micropaleontología, 42, 11-35, 2010.

Mette, W. and Mohtat-Aghai, P.: Late Permian and Early Triassic microfossil assemblages of Iran, Berichte des Instituts für Erdwissenschaften Karl-Franzens Universität Graz, 9, 263-265, 2004.

Mohtat Aghai, P., Vachard, D., and Krainer, K.: Transported foraminifera in Palaeozoic deep red nodular limestones exemplified by latest Permian Neoendothyra in the Zal section (Julfa area, NW Iran), Revista española de micropaleontología, 41, 197-213, 2009.

Muttoni, G., Gaetani, M., Kent, D. V., Sciunnach, D., Angiolini, L., Berra, F., Garzanti, E., Mattei, M., and Zanchi, A.: Opening of the Neo-Tethys Ocean and the Pangea B to Pangea A transformation during the Permian, GeoArabia, 14, 17-48, 2009a.

Muttoni, G., Mattei, M., Balini, M., Zanchi, A., Gaetani, M., and Berra, F.: The drift history of Iran from the Ordovician to the Triassic, Geological Society, London, Special Publications, 312, 7-29, 2009b.

Perri, M. C. and Farabegoli, E.: Conodonts across the PermianTriassic boundary in the Southern Alps, Courier Forschungsinstitut Senckenberg, 245, 281-313, 2003.

Prinoth, H. and Posenato, R.: Late Permian Nautiloids from the Bellerophon Formation of the Dolomites (Italy), Palaeontogr. Abt. A, 282, 135-165, 2007.

Pruss, S. B., Corsetti, F. A., and Bottjer, D. J.: The unusual sedimentary rock record of the Early Triassic: a case study from the southwestern United States, Palaeogeogr. Palaeocl., 222, 33-52, 2005.

Pruss, S. B., Bottjer, D. J., Corsetti, F. A., and Baud, A.: A global marine sedimentary response to the end-Permian mass extinction: Examples from southern Turkey and the western United States, Earth Sci. Rev., 78, 193-206, 2006.

Rampino, M. R. and Caldeira, K.: Major perturbation of ocean chemistry and a "Strangelove Ocean" after the end-Permian mass extinction, Terra Nova, 17, 554-559, 2005.
Reed, F. R. C.: New fossils from the Productus Limestones of the Salt Range, with notes on other species, Memoirs of the Geological Survey of India, Palaeontologia Indica, 17, 1-56, 1931.

Reed, F. R. C.: Brachiopoda and Mollusca from the Productus limestones of the Salt Range, Palaeontologia Indica, New Series, 23, $1-768,1944$.

Richoz, S.: Stratigraphie et variations isotopiques du carbone dans le Permien supérieur et le Trias inférieur de quelques localités de la Néotéthys (Turquie, Oman et Iran), Memoirs de Géologie (Lausanne), 1-251, 2006.

Richoz, S., Krystyn, L., Baud, A., Brandner, R., Horacek, M., and Mohtat-Aghai, P.: Permian-Triassic boundary interval in the Middle East (Iran and N. Oman): Progressive environmental change from detailed carbonate carbon isotope marine curve and sedimentary evolution, J. Asian Earth Sci., 39, 236-253, 2010.

Ridgwell, A.: A Mid Mesozoic Revolution in the regulation of ocean chemistry, Mar. Geol., 217, 339-357, 2005.

Rostovtsev, K. O. and Azaryan, N. R.: The Permian-Triassic Boundary in Transcaucasia, Canadian Society of Petroleum Geologists SpecialPublications, 2, 89-99, 1973.

Rothman, D. H., Fournier, G. P., French, K. L., Alm, E. J., Boyle, E. A., Cao, C., and Summons, R. E.: Methanogenic burst in the endPermian carbon cycle, P. Natl. Acad. Sci. USA, 111, 5462-5467, 2014.

Ruban, D. A., Al-Husseini, M. I., and Iwasaki, Y.: Review of Middle East Paleozoic plate tectonics, GeoArabia, 12, 35-56, 2007a.

Ruban, D. A., Zerfass, H., and Yang, W.: A new hypothesis on theposition of the Greater Caucasus Terrane in the Late PalaeozoicEarly Mesozoic based on palaeontologic and lithologic data, Trabajos de Geologia, 27, 19-27, 2007b.

Ruzhencev, V. E. and Shevyrev, A. A.: Ammonoidei, in: Razvitie i smena morskikh organizmov na Rubezhe Paleozoya i Mezozoya, edited by: Ruzhencev, V. E. and Sarytcheva, T. G., Trudy Paleontologicheskogo Instituta Akademiya Nauk SSSR, 108, 47-57, 1965.

Ruzhencev, V. E., Sarytcheva, T. G., and Shevyrev, A. A.: Biostratigraficheskie vyvody, in: Rasvitie i smena morskikh organizmov na rubezhe Paleozoya i Mezozoya, edited by: Ruzhencev, V. E. and Sarytcheva, T. G., Trudy Paleontologicheskogo Instituta Akademiya Nauk SSSR, 108, 93-116, 1965.

Sarytcheva, T. G. and Sokolskaja, A. N.: Otryad Productida, in: Rasvitie i smena morskikh organizmov na rubezhe Paleozoya i Mezozoya, edited by: Ruzhencev, V. E. and Sarytcheva, T. G., Trudy Paleontologicheskogo Akademiya Nauk SSSR, 108, 209232, 1965.

Schobben, M., Joachimski, M. M., Korn, D., Leda, L., and Korte, C.: Palaeotethys seawater temperature rise and an intensified hydrological cycle following the end-Permian mass extinction, Gondwana Res., 26, 675-683, 2014.

Schobben, M., Stebbins, A., Ghaderi, A., Strauss, H., Korn, D., and Korte, C.: Flourishing ocean drives the end-Permian marine mass extinction, P. Natl. Acad. Sci. USA, 112, 10298-10303, 2015.

Schobben, M., Stebbins, A., Ghaderi, A., Strauss, H., Korn, D., and Korte, C.: Eutrophication, microbial-sulfate reduction and mass extinctions, Communicative and Integrative Biology, 9, e1115162, https://doi.org/10.1080/19420889.2015.1115162, 2016.

Schobben, M., van de Velde, S., Gliwa, J., Leda, L., Korn, D., Struck, U., Ullmann, C. V., Hairapetian, V., Ghaderi, A., Korte, 
C., Newton, R. J., Poulton, S. W., and Wignall, P. B.: Latest Permian carbonate carbon isotope variability traces heterogeneous organic carbon accumulation and authigenic carbonate formation, Clim. Past, 13, 1635-1659, https://doi.org/10.5194/cp-131635-2017, 2017.

Schobben, M., Heuer, F., Tietje, M., Ghaderi, A., Korn, D., Korte, C., and Wignall, P. B.: Chemostratigraphy Across the PermianTriassic Boundary: The Effect of Sampling Strategies on Carbonate Carbon Isotope Stratigraphic Markers, in: Chemostratigraphy Across Major Chronological Boundaries, Geophysical Monograph 240, First Edition, edited by: Sial, A. N., Gaucher, C., Muthuvairavasamy, R., and Valderez, P. F., John Wiley \& Sons, Inc., 159-181, 2019.

Scholle, P. A. and Arthur, M. A.: Carbon isotope fluctuations in Cretaceous pelagic limestones: potential stratigraphic and petroleum exploration tool, AAPG Bull., 64, 67-87, 1980.

Schubert, J. K. and Bottjer, D. J.: Aftermath of the Permian-Triassic mass extinction event: Paleoecology of Lower Triassic carbonates in the western USA, Palaeogeogr. Palaeocl., 116, 1-39, 1995.

Sedlacek, A. R., Saltzman, M. R., Algeo, T. J., Horacek, M., Brandner, R., Foland, K., and Denniston, R. F.: ${ }^{87} \mathrm{Sr} /{ }^{86} \mathrm{Sr}$ stratigraphy from the Early Triassic of Zal, Iran: Linking temperature to weathering rates and the tempo of ecosystem recovery, Geology, 42, 779-782, 2014.

Shen, S.-Z.: The conodont species Clarkina orientalis (Barskov \& Koroleva, 1970) and its spatial and temporal distribution, Permophiles, 50, 25-37, 2007.

Shen, S.-Z. and Mei, S.-L.: Lopingian (Late Permian) highresolution conodont biostratigraphy in Iran with comparison to South China zonation, Geol. J., 45, 135-161, 2010.

Shevyrev, A. A.: Nadortyad Ammonoidea, in: Rasvitie i smena morskikh organizmov na rubezhe Paleozoya i Mezozoya, edited by: Ruzhencev, V. E. and Sarytcheva, T. G., Trudy Paleontologicheskogo Instituta Akademiya Nauk SSSR, 108, 166-182, 1965.

Shevyrev, A. A. and Ermakova, S. P.: A Contribution to the Systematics of Ceratites, Paleontologicheskiy Zhurnal, 1979, 52-58, 1979.

Shimansky, V. N.: Podotryad Nautiloidea, in: Razvitie i smena morskikh organizmov na Rubezhe Paleozoya i Mezozoya, edited by: Ruzhencev, V. E. and Sarytcheva, T. G., Trudy Paleontologicheskogo Instituta Akademiya Nauk SSSR, 108, 157-165, 1965.

Sokolskaja, A. N.: Otryad Orthida, in: Razvitie i smena morskikh organizmov na Rubezhe Paleozoya i Mezozoya, edited by: Ruzhencev, V. E. and Sarytcheva, T. G., Trudy Paleontologicheskogo Instituta Akademiya Nauk SSSR, 108, 198-203, 1965.

Stampfli, G. M. and Borel, G. D.: A plate tectonic model for the Paleozoic and Mesozoic constrained by dynamic plate boundaries and restored synthetic oceanic isochrons, Earth Planet. Sc. Lett., 196, 17-33, 2002.

Stampfli, G. M. and Borel, G. D.: The TRANSMED transects in space and time: constraints on the paleotectonic evolution of the Mediterranean domain, in: The TRANSMED Atlas, The Mediterranean region from crust to mantle, Springer, 53-80, 2004.
Stepanov, D. L., Golshani, F., and Stöcklin, J.: Upper Permian and Permian-Triassic Boundary in North Iran., Geolological Survey of Iran, Report, 12, 1-72, 1969.

Stoyanow, A. A.: On the character of the boundary of Palaeozoic and Mesozoic near Djulfa, Zapiski Imperatorskago St.Peterburgskago Mineralogiceskago Obscestva = Verhandlungen der Russisch-Kaiserlichen Mineralogischen Gesellschaft zu St. Petersburg, 2. Serie, 47, 61-135, 1910.

Sun, Y., Joachimski, M. M., Wignall, P. B., Yan, C., Chen, Y., Jiang, H., Wang, L., and Lai, X: Lethally hot temperatures during the Early Triassic greenhouse, Science, 338, 366-370, 2012.

Svensen, H., Planke, S., Polozov, A. G., Schmidbauer, N., Corfu, F., Podladchikov, Y. Y., and Jamtveit, B.: Siberian gas venting and the end-Permian environmental crisis, Earth Planet. Sc. Lett., 277, 490-500, 2009.

Swart, P. K.: Global synchronous changes in the carbon isotopic composition of carbonate sediments unrelated to changes in the global carbon cycle, P. Natl. Acad. Sci. USA, 105, 13741-13745, 2008.

Taraz, H., Golshani, F., Nakazawa, K., Shimizu, D., Bando, Y., Ishii, K.-i., Murata, M., Okimura, Y., Sakagami, S., and Nakamura, K.: The Permian and the Lower Triassic systems in Abadeh region, central Iran, Mem Fac Sci Kyoto Univ. Ser. Geol. Miner., 47, 62-133, 1981.

Teichert, C. and Kummel, B.: Nautiloid cephalopods from the Julfa Beds, Upper Permian, Northwest Iran., Bulletin of the Museum of Comparative Zoology, Harvard University, 144, 409-434, 1973.

Teichert, C., Kummel, B., and Sweet, W. C.: Permian-Triassic strata, Kuh-e-Ali Bashi, Northwestern Iran, Bulletin of the Museum of Comparative Zoology, Harvard University, 145, 359472, 1973.

von Arthaber, G. : Das jüngere Paläozoicum aus der Araxes-Enge bei Djulfa, Beiträge zur Paläontologie Österreich-Ungarns und des Orients, 12, 209-302, 1900.

von Möller, V.: Üeber die bathrologische Stellung des jüngeren paläozoischen Schichtensystems von Djoulfa in Armenien, Neues Jahrbuch für Mineralogie, Geol. Palaeontol., 1879, 225$243,1879$.

Waagen, W.: Salt Range fossils, 1. Productus Limestone fossils, Palaeontologia Indica, 1, 1-85, 1879

Wang, C.: Conodont evolutionary lineage and zonation for the Latest Permian and the Earliest Triassic, Permophiles, 29, 30-37, 1996.

Wang, C. and Wang, S.: Conodonts from Permian-Triassic boundary beds in Jiangxi, China and evolutionary lineage of Hindeodus-Isarcicella, Acta Palaeontol. Sin., 36, 151-178, 1997.

Wang, C. and Wang, Z.: Permian conodont biostratigraphy of China, Geological Society of America, Special Paper, 187, 227 236, 1981.

Wang, K., Geldsetzer, H. H. J., and Krouse, H. R.: Permian-Triassic extinction: Organic $\delta^{13} \mathrm{C}$ evidence from British Columbia, Canada, Geology, 22, 580-584, 1994.

Wang, S.: Late Permian and Early Triassic ostracods of western Guizhou and northeastern Yunnan, Acta Palaeontol. Sin., 7, 277 308, 1978.

Wignall, P. B. and Twitchett, R. J.: Extent, duration, and nature of the Permian-Triassic superanoxic event, Special Papers, Geol. Soc. Am., 356, 395-414, 2002. 
Wignall, P. B., Newton, R., and Brookfield, M. E.: Pyrite framboid evidence for oxygen-poor deposition during the PermianTriassic crisis in Kashmir, Palaeogeogr. Palaeocl., 216, 183-188, 2005.

Winguth, C. and Winguth, A. M. E.: Simulating Permian-Triassic oceanic anoxia distribution: Implications for species extinction and recovery, Geology, 40, 127-130, 2011.

Woods, A. D., Bottjer, D. J., Mutti, M., and Morrison, J.: Lower Triassic large sea-floor carbonate cements: their origin and a mechanism for the prolonged biotic recovery from the end-Permian mass extinction, Geology, 27, 645-648, 1999.

Xie, S., Pancost, R., Huang, X., Jiao, D., Lu, L., Huang, J., Yang, F., and Evershed, R.: Molecular and isotopic evidence for episodic environmental change across the Permo/Triassic boundary at Meishan in South China, Glob. Planet. Change, 55, 56-65, 2007.

Yin, H., Zhang, K., Tong, J., Zunyi, Y., and Wu, S.: The Global Stratotype Section and Point (GSSP) of the Permian-Triassic Boundary, Episodes, 24, 102-114, 2001.

Yin, H., Xie, S., Luo, G., Algeo, T. J., and Zhang, K.: Two episodes of environmental change at the Permian-Triassic boundary of the GSSP section Meishan, Earth-Sci. Rev., 115, 163-172, 2012.

Yuan, D., Shen, S., Henderson, C. M., Chen, J., Zhang, H., and Feng, H.: Revised conodont-based integrated high-resolution timescale for the Changhsingian Stage and end-Permian extinction interval at the Meishan sections, South China, Lithos, 204, 220-245, 2014.
Zakharov, Y. D.: The Permo-Triassic boundary in the southern and eastern USSR and its intercontinental correlation, edited by: Sweet, W. C., Zunyi, Y., Dickins, J. M., and Hongfu, Y., Cambridge University Press, Cambridge, 46-55, 1992.

Zakharov, Y. D., Biakov, A., Baud, A., and Kozur, H.: Significance of Caucasian sections for working out carbon-isotope standard for Upper Permian and Lower Triassic (Induan) and their correlation with the Permian of north-eastern Russia, J. China Univ. Geosci., 16, 141-151, 2005.

Zeebe, R. E. and Westbroek, P.: A simple model for the $\mathrm{CaCO}_{3}$ saturation state of the ocean: The "Strangelove," the "Neritan," and the "Cretan" Ocean, Geochem. Geophy. Geosy., 4, 1-24, 2003.

Zhang, F., Romaniello, S. J., Algeo, T. J., Lau, K. V., Clapham, M. E., Richoz, S., Herrmann, A. D., Smith, H., Horacek, M., and Anbar, A. D.: Multiple episodes of extensive marine anoxia linked to global warming and continental weathering following the latest Permian mass extinction, Sci. Adv., 4, e1602921, https://doi.org/10.1126/sciadv.1602921, 2018.

Zhao, J., Liang, X., and Zheng, Z.: Late Permian cephalopods from South China, Palaeontol. Sin. Ser. B, 12, 1-194, 1978. 